\title{
Expectations after expecting: the impact of first birth on the fertility expectations of one child women in the USA and UK
}

\begin{abstract}
Expectations for having children are hypothesised to be predominantly influenced by societal family norms at young ages, and are adjusted during the life course in response to changing circumstances and new information. The onset of parenthood is likely to be a key event that affects expectations. This paper explores whether the expectations of women who have only one child (one child women) change in the five years before and after first birth, using the National Longitudinal Survey of Youth 1979 (USA) and Understanding Society (UK). We aim to determine whether one child women are distinct in their expectations from women who go on to higher parities even before first birth, and whether the event of first birth is a catalyst for changing expectations.
\end{abstract}

Our results show that, in both contexts, one child women expect closer to two children prior to, compared to after, first birth, when the trajectory declines more steeply towards one. One child women also expect fewer than higher parity mothers by the time of first birth. Our findings suggest that although one child women already expect fewer children compared to other mothers prior to first birth, their expectations are particularly affected by the onset of parenthood.

Keywords: fertility, fertility expectations, fertility intentions, stability of expectations, lifecourse 


\section{Introduction}

High-income, low-fertility countries have an 'unmet need' for children: over the last 50 years, these countries have observed a mean ideal family size (the average number of children individuals consider ideal for a family to have) around two, and yet the average number of children has consistently fallen below this (Beaujouan \& Berghammer, 2019; Harknett \& Hartnett, 2014; Lutz, 2007; Philipov, 2009; Testa, 2012). This difference between an ideal of two and achieved below replacement fertility is commonly known as the 'fertility gap'. Demographers have postulated that differences in observed fertility between countries are more likely to be explained by differences in the ability of individuals to realise their expectations, rather than differences in expected fertility (Beaujouan \& Berghammer, 2019; Bongaarts, 2001). This implies that certain factors are impeding individuals from achieving their goals. However, averaging both fertility experiences and ideals across all individuals to calculate the gap is likely to conceal individual heterogeneity in both measures (Harknett \& Hartnett, 2014; Morgan \& Rackin, 2010). For example, a gap between a mean ideal family size of two and actual fertility of 1.7 could be decomposed into many people intending three but having none amongst others who meet their ideal of one or two, or into many wanting two and having one.

This paper seeks to improve our understanding of the "fertility gap" by exploring how and when expectations for children change among a specific parity group: women who only have one child (one child women). There is a growing literature on the expectations of women who never have children (Albertini \& Brini, 2020; Fiori, Rinesi, \& Graham, 2017; Gemmill, 2019; Gray, Evans, \& Reimondos, 2013; Maximova \& Quesnel-Vallée, 2009; Mynarska, Matysiak, Rybińska, Tocchioni, \& Vignoli, 2015; Rybinska \& Morgan, 2019), but very little analyses focus on one child women, who are also having fewer than the normative ideal of two. This is an overlooked group considering one child women make up an increasing proportion of mothers (Frejka, 2008; Frejka \& Sardon, 2007), particularly in Southern, Central and Eastern 
Europe (Billari \& Kohler, 2004; Frejka \& Gietel-Basten, 2016). One child women are likely to be different to women who have no children, for example they might be more certain about having children, than women with no children, but are also likely to be different compared to women who have the normative two children. Together this poses the question: do women who only have one child always plan to have one child? Or do they initially subscribe to the strong societal norm of two and revise downwards over time?

Further, this paper clarifies the role of first birth in this 'expectation pathway'. First birth is a time point of considerable change in terms of subjective well-being and mental health (Luppi \& Mencarini, 2018; Myers, Burger, \& Johns, 2016), household burden and division of labour (Campolo, Pino, \& Rizzi, 2020; DeRose et al., 2019; Kühhirt, 2012), and employment arrangements and earnings (Baxter, Hewitt, \& Haynes, 2008; Evertsson, 2013). This paper therefore not only addresses the contribution of one child women to the fertility gap, but also whether having a child acts as the catalyst for revising expectations for these women.

\section{Background}

\section{Expectations Over the Life Course}

The motivational sequence leading to fertility behaviour is characterised in the demographic literature by many different concepts and terms (Miller, 2011). The fertility gap uses mean ideal family size as its measure of comparison to achieved fertility. The measure is thought to be highly reflective of societal family norms (Philipov \& Bernardi, 2011; Trent, 1980), and does not always translate to the individual's personal desire for children (Quesnel-Vallee \& Morgan, 2003). This paper therefore focuses specifically on childbearing expectations: the number of children wanted by the individual accounting for perceived obstacles outside of the individual's control (Miller, 2011). Conceptually expectations are close to childbearing intentions, which represent a commitment to act on the plan to have a child (Miller, 2011). 
Stated expectations and intentions are nearly identical in empirical studies; we therefore refer to previous literature on both concepts.

Psychosocial theories of reproductive decision-making, such as the cognitive-social model (Bachrach \& Morgan, 2013), outline that expectations in early life are more likely to be informed by the individual's childhood family experiences and normative family size ideals. Expectations are therefore considered to be at their most 'unrealistic' and uncertain at younger ages, given the inability to foresee future circumstances. During the life course, expectations will be revised based on 'critical junctures' in the life course (e.g. having a partner), competing preferences (e.g. career goals that are incompatible with family goals) and new knowledge (e.g. having a child). The Traits-Desires-Intentions-Behaviour framework (TDIB) outlines a potential mechanism for how expectations can be altered over time by linking them in a pathway. Initial motivations for children (traits or dispositions to feel, think and act in ways that affect childbearing) are biologically based and non-conscious (Miller, 2011). These motivations form desires for children (the ideal childbearing goal in the presence of no obstacles), before being translated into intentions which consider the probability of their execution. Intentions are implemented through instrumental behaviours such as aiming to achieve or avoid conception. However, partner's intentions, life course factors and fecundity issues can impede the ability of the individual to successfully achieve a birth. The framework outlines how desires and intentions will change over time because of situational factors, many of which are affected by the event of a first birth.

Previous studies have sought to examine the reasons for changes in expectations over the life course. Although some have used cross-sectional samples to infer change (Testa \& Grilli, 2006), the more convincing explorations come from studies that follow individuals longitudinally. Putting to one side a growing literature on expectations over time among childless individuals, studies looking at expectations among women with children find that 
there is a considerable number who do have stable expectations, particularly among those desiring two children (Heiland, Prskawetz, \& Sanderson, 2008; Quesnel-Vallee \& Morgan, 2003) and in USA analyses (Quesnel-Vallee \& Morgan, 2003; Ray, Harcey, Greil, Tiemeyer, \& McQuillan, 2018). The studies also highlight, however, sizeable adjustments of intentions over the life course among other groups. Change over time has been explained by various factors including partnership status (Gray et al., 2013; Hayford, 2009; Iacovou \& Tavares, 2011; Liefbroer, 2009; Mitchell \& Gray, 2007), education (Dey \& Wasoff, 2010; Liefbroer, 2009; Ray et al., 2018), the labour market (Gray et al., 2013; Heiland et al., 2008; Liefbroer, 2009; Ray et al., 2018), religion (Heiland et al., 2008; Ray et al., 2018), number of siblings (Dey \& Wasoff, 2010; Heiland et al., 2008) and expectations for more than two children (Quesnel-Vallee \& Morgan, 2003). Postponement of childbearing to the thirties, in particular, has been associated with adjustment of intentions downwards over time compared to those who start childbearing earlier (Liefbroer, 2009), as has age more generally, with those in their thirties expecting fewer than those in their twenties (Dey \& Wasoff, 2010; Hayford, 2009; Heiland et al., 2008; Quesnel-Vallee \& Morgan, 2003). In the USA, increases in expectations over time were associated with initially desiring fewer than two children (Quesnel-Vallee \& Morgan, 2003) and with sequential childbearing. The size of the effect, however, appears larger for higher parities (Heiland et al., 2008; Miller \& Pasta, 1995; Ray et al., 2018) and for those who have positive previous birth experiences (Iacovou \& Tavares, 2011).

In terms of parity specific adjustments, psychosocial theories of fertility behaviour outline that childbearing decisions are adjusted after the birth of each child (Miller \& Pasta, 1995; Udry, 1983). Until a particular birth occurs, individuals are not able to experience and learn exactly what they enjoy or dislike about this stage of parenthood and evaluate whether they would like to have a further birth. This is particularly true for first births and the advent of parenthood. The literature reports mixed findings on the relationship between first births and changing 
fertility expectations. Gisser et al. (1985) found no evidence of a 'baby shock' (i.e. that having a first child causes fertility desires to be revised downwards) in Austria. Miller and Pasta (1995) found evidence of upwards revisions as a result of a birth in the US, but Ray et al. (2018) found that US women who had one child were less likely to increase their fertility ideals over time compared to maintaining stable intentions. Furthermore, although the addition of 'a child' was associated with increased fertility ideals over time, the first child was not. Iacovou and Tavares (2011) found that first births occurring to UK individuals who expected to only have one child were associated with increasing expectations, but both upwards and downwards revisions were common for those who expected to have more than one child prior to first birth. The authors conclude that revisions are less related to parity and more to the individual's closeness to reaching their expectations target prior to the birth.

\section{Fertility Background of Study Countries}

Psychosocial theories of fertility behaviour assume that prior to first birth and at young ages, expectations predominantly reflect normative ideals and become more diverse as the life course progresses. However, there are no comparative studies to explore whether this is generalisable across settings. Although statistically testing the comparison between countries is challenging because of differences in datasets, comparing national samples descriptively can still provide insight into whether one child women share a common experience in their expectation trajectories over time across contexts, and whether there is evidence of a persistent fertility gap at the individual level for these women. By extension, if there are differences, contextual explanatory factors can be explored in a comparative setting. We have therefore chosen to compare expectations in the USA and the UK.

Both countries included in this paper have relatively high childbearing for low-fertility countries, a prevalent two-child family norm and their $20^{\text {th }}$ century fertility decline has been largely driven by fewer large families among birth cohorts of the 1940s and later (Zeman, 
Beaujouan, Brzozowska, \& Sobotka, 2018). They also both have 'liberal' welfare regimes (Esping-Andersen, 1990). Liberal countries are characterised by a lack of state support for families, requiring families to rely on market employment for income, and using that income on market services to allow them to combine work and family. The two countries are compared in more detail below.

\section{USA context}

Compared to other low-fertility countries, the US has seen relatively high fertility around replacement level across the last 30 years, with a young mean age of first birth (between 24 to 27). In terms of cohort fertility, there has been a gradual decline towards smaller families, but in $201867 \%$ of all women aged 40-44 had at least two children, with two children being most common (35\% of all families) (Guzzo \& Schweizer, 2020). The proportion with one child increased to a high of $19 \%$ in 2000, but remained stable since then (Guzzo \& Schweizer, 2020). Fertility in the US is also strongly distinguished by demographic groups: Latina women, women who do not finish high school and religious Catholics have some of the highest fertility rates among population subgroups (Gemmill \& Hartnett, forthcoming).

Period fertility has been declining recently as a result of postponed childbearing for all birth parities, particularly among teens and young women (Gemmill \& Hartnett, forthcoming). Whether cohort fertility will be affected by this postponement will depend on the ability of these cohorts to 'catch up' and meet their fertility goals at later ages. There has been little evidence of this in other high income regions with typically higher fertility, like Nordic countries (Hellstrand et al., 2020), but there is some evidence of catching up in US women in their 30s and 40s (Gemmill \& Hartnett, forthcoming).

In terms of expectations for children, both period and cohort measures of expectations are very close to observed fertility, with a small "fertility gap" between 1.97 (CFR) and 2.22 (ideal) 
(Beaujouan \& Berghammer, 2019; Morgan \& Rackin, 2010). Morgan and Rackin (2010) show, however, that this is less a result of US women successfully achieving their intentions, but rather an overall balance in errors between those that over and under achieve their intentions. Indeed, the US is unique for having one of the highest unintended pregnancy rates among highincome countries (Singh, Sedgh, \& Hussain, 2010), and recently observed reductions in the rate have been identified as a primary driver for falling US fertility alongside declining fertility amongst Latina women (Gemmill \& Hartnett, forthcoming). Repeated postponement of fertility, lack of a suitable partner and declining fecundity with age were identified as important obstacles for the group that do not realise their intentions for children (Morgan \& Rackin, 2010)

\section{UK context}

Compared to the US, the UK has a later mean age at first birth (28.95 vs 27.37, (Human Fertility Database, 2020)) and a lower TFR (1.68 vs 1.73, (Human Fertility Database, 2020)). However, fertility is not as low as in some high-income contexts, fluctuating between a low of 1.63 in 2001 and high of 1.91 in 2011, with latest CFR estimates at 1.84 (ONS, 2019). There is also, relative to the rest of Europe, a persistent 'hump' in the fertility schedule at younger ages, with a high teenage pregnancy rate (Rendall et al., 2005). There is therefore considerable dispersion in the tempo of UK childbearing, with both significant young childbearing and an increasing mean age of first birth.

As in the USA, the UK has witnessed a fertility postponement (ONS, 2019), as well as an increasing proportion of childless women (ONS, 2019; Shkolnikov, Andreev, Houle, \& Vaupel, 2007), one child women (ONS, 2019), and a decreasing proportion of large families (Smallwood, 2002). However, two child families remain the most common (ONS, 2019). As with the tempo of childbearing, the dispersion in family size is more than that observed in other European countries: a higher level of childlessness, a low percentage of one child women and relatively more women with two or more children (Shkolnikov et al., 2007). 
UK childbearing has therefore typically been characterised as polarised between different population subgroups (Sigle-Rushton, 2008). In particular, highly educated women are most likely to be childless (Berrington, Stone, \& Beaujouan, 2015), and postpone fertility to later ages (Berrington, 2004). The fertility of non-UK born mothers is higher than native born mothers (Coleman \& Dubuc, 2010; Tromans, Natamba, \& Jefferies, 2009). Employment, age, geography and partnership characteristics are also important (Berrington, 2004; Fiori, Graham, \& Feng, 2014)

In terms of intentions for children, whilst there has been a general decline in average intentions over time, mean ideal family size remains around two (Ní Bhrolcháin, Beaujouan, \& Berrington, 2010; Smallwood \& Jefferies, 2003). The latest estimated gap is small, between 0.2 and 0.3 (Smallwood \& Jefferies, 2003). However, this has a marked educational gradient, with higher educated women having a larger gap than less educated women, for whom the gap is almost non-existent (Beaujouan \& Berghammer, 2019; Berrington \& Pattaro, 2014). The degree of certainty in intentions is also variable by group, particularly prevalent at younger ages and unpartnered women (Ní Bhrolcháin \& Beaujouan, 2011). This is matched by declining intentions for two children as women age, switching to one or none, and increasing diversity in intentions away from two over time (Ní Bhrolcháin et al., 2010). Of particular interest to this research question, among women with children, uncertainty in intentions is very prevalent among one child women. $38 \%$ of one child women were estimated to be uncertain about continued childbearing, which is higher than for women with two $(23 \%)$ or more than two children (16\%) (Ní Bhrolcháin \& Beaujouan, 2011).

\section{Research questions}

This paper aims to explore the trajectories of fertility expectations around first birth for women who only have one child in the USA and the UK. We test whether first birth acts as a "critical 
juncture' resulting in revised expectations, and compare our findings in each country. Specifically, we address three research questions:

Question 1: Do one child women experience a decline in fertility expectations after first birth?

In the years prior to first birth, we would predict expectations among one child women to be closer to two as they will primarily reflect normative family size and background factors (Rackin \& Bachrach, 2016). As life progresses expectations will instead reflect life experience and new knowledge, in this case the birth of the first child. We therefore anticipate one child women to revise their expectations downwards after first birth, rather than sustaining an ideal of two.

Question 2: Do one child women experience a decline in expectations after first birth not seen for higher parity women?

In the five years prior to first birth, we expect mothers of all parities to have similar expectations, reflecting normative ideal family size. After first birth, we anticipate mothers that go on to higher parities to remain stable in their expectations whereas one child women will follow a downwards trajectory.

Question 3: Are there any characteristics of one child women which are particularly associated with changes in trajectories over time?

Based on prior research, in the US we expect that one child women will be demographically select. For example, they will be less likely to be Latina, Roman Catholic and less educated, since these demographic groups tend to have higher fertility. Similarly, in the UK, we predict that one child women will be less likely to have a lower level of completed education and less likely to have a partner. In terms of whether the characteristics of one child women are associated with differences in trajectories, if such women are mainly from demographic groups with lower fertility then our analysis will have little power to detect differences in trajectories 
between demographic groups. Otherwise, we expect to see steeper revisions over time associated with demographic characteristics which typically indicate higher fertility (such as religiosity and partnership).

\section{Data and Methods}

\section{Methods}

To observe typical trajectories in expected family size at the time of first birth, we use poisson mixed-effect models. Repeat observations are clustered over time (level one) within an individual (level two) to account for both the individual's time-invariant and time-varying characteristics. This type of model is similar to a linear growth curve (hierarchical cluster) model. However, a linear growth curve model would be inappropriate for our analysis given expectations for children are a count variable and the linear model uses a normal distribution. In this analysis, we therefore use a poisson distribution with log as the link function of the model to account for the discrete nature of the outcome variable.

Trajectories in expected family size are calculated for the interval five years before to five years after birth. Time is operationalised as months either side of first birth. As we expect larger changes to occur in the period after first birth, splines are added to allow the trajectory to vary at different time points. The addition of splines means we can explore whether revisions of expectations are likely to occur within a particular year after birth, and by extension suggest why women might be revising their expectations. For example, drops soon after birth may be more likely to be linked with a difficult pregnancy or birth experience, whereas revisions later might suggest difficulties managing caring responsibilities. Splines are added at the month of birth, one year after month of birth, two years after month of birth, three years after month of birth and four years after month of birth. The p-value for the splines evaluates whether there is 
a significant difference between the slope of the spline interval and the slope of the first interval (the period before pregnancy).

The variable of interest to this paper is expected family size (i.e. the number of children one has plus any more expected). However, evaluations of expected family size are fundamentally altered by first pregnancy, making the period before and after birth incomparable. Once a woman is pregnant or has her first child, she must factor that child into her fertility expectations, meaning that expected family size cannot be lower than one. This introduces a problem as the data is then zero-truncated and no longer follows a poisson distribution. To overcome this issue, we modelled the outcome of additional number of children expected. This is equivalent to expected family size prior to first pregnancy. After first pregnancy, we then add one (to account for the first child) to all figure illustrations of the model estimates to represent total expected family size. Pregnant individuals are included in this group if they either declare that they are pregnant in the survey (i.e. demonstrating they know they are pregnant and are factoring this into their childbearing expectations), or if they are at least two months pregnant as we assume from this point onwards most will know they are pregnant. All UK one child women who were two or more months pregnant also declared that they were pregnant, and in the absence of complete pregnancy data in the US data we assumed the same would apply.

However, by correcting for zero-truncation through using additional number of children, a new problem is created in the model: that once an individual is pregnant/has a child they will revise their additional number expected downwards by at least a factor of one to reflect the child they are pregnant with or had. This makes it appear like there is therefore a steep revision in expectations at pregnancy, when in fact it is just a reflection of the model moving from predicting total expected family size (as the individual has no children) to number of additional children expected in addition to the child had. To account for this, we therefore include a control for whether the woman was pregnant/had had their first child at the time of observation. 
The specification of our model is therefore:

$$
\text { 1) } \quad \log \left(Y_{i j}\right)=\beta_{0 j}+\beta_{1 j} \text { Months }_{i j}+\beta_{z} X_{i j}
$$

Where:

$$
\begin{aligned}
& \text { 1a) } \beta_{0 j}=\gamma_{00}+U_{0 j} \\
& \text { 1b) } \beta_{1 j}=\gamma_{10}+U_{1 j}
\end{aligned}
$$

The number of additional children expected for an individual at a given month around first birth $\left(\log \left(Y_{i j}\right)\right)$ is predicted by the person-specific intercept (random intercept, $\left.\beta_{0 j}\right)$ and the person-specific effect of months around first birth (random slope, $\beta_{1 j} M o n t h s_{i j}$ ). The person-specific intercept and slope can be divided into an average effect $(\gamma)$ and the personspecific residual from this average effect (U). Lastly, a set of fixed covariates are added to the prediction $\left(\beta_{z} X_{i j}\right)$.

The fixed covariates in the 'empty' model are the splines and a control for whether the individual is not yet pregnant. In the multivariable models, demographic characteristics not affected by first birth (detailed in the following section) were added to this fixed part of the equation in a sequential manner. We do not include covariates that are likely to change around first birth, such as employment status, household division of labour and well-being. Disentangling the causal pathway of changes in these variables occurring around first birth requires more complex statistical methodologies (Berrington, Hu, Smith, \& Sturgis, 2007). To allow for variation over time, interactions of the covariates with months around first birth were tested and included in the multivariable model if significant $(\mathrm{p}<0.05)$.

As part of robustness checks, to see whether correction was needed for overdispersion, a random intercept was also added at level one (observations). However, as the variance for the parameter was consistently close to 0 across models, this illustrated minimal overdispersion 
and thus we do not include this parameter in the presented models. The data and presented models are detailed in the following section.

\section{Data and Measures}

\section{UK Sample}

The UK data combine waves from the British Household Panel Survey (BHPS) with Understanding Society (together known as UK Household Longitudinal Survey, UKHLS) that have information on childbearing expectations (University of Essex: Institute for Social and Economic Research, 2020). Specifically, we draw on BHPS waves 2 (1992), 8 (1998), 11 (2001), 12 (2002), 13 (2003), 17 (2007) and Understanding Society wave 5 (2013-2014) which asked:

1) Thinking about your plans for the future, do you think you will have any (more) children?

2) How many more/many children do you think you will have?

Although the time points are unequally spaced due to data restrictions for our outcome of interest, multilevel models can account for this as well as partially missing data (Curran, Obeidat, \& Losardo, 2010). BHPS initially sampled a representative sample of 5500 households from across Great Britain. A booster sample was added in 1999 for Scotland and Wales, and again in 2001 for Northern Ireland. Understanding Society commenced in 2009 adding a sample of 40,000 households and combining BHPS households from its second wave (2010-2011). All household members over 16 are asked to complete an individual questionnaire and are followed up over the waves.

To select our sample, we first restricted to women who were known to have had their first child by the last wave of all data collection (2017) and have complete information on that child's year of birth and their fertility expectations. To better compare higher parity and one child 
women, we then added a censor at second childbirth for higher parity women so that fertility expectations after second birth were excluded from analysis (given that the additional number of expected children would change for women after having their second birth). As the mixedeffect model requires at least three observations per individual (Curran et al., 2010), women with fewer observations were dropped from the sample. We also required all observations to be within ten years either side of the first birth, and at least two of the observations to be within five years either side of first birth so that we are able to capture change at this time point. Further, those with a first birth prior to 1990 were dropped as all had observations falling outside the period of interest (five years before to five years after first birth). This left a sample of 303 mothers and 1102 observations (Model 1). The second model is only fitted for women who, as far as is known, only had one child. This model included 192 women, with 718 observations (Model 2). This sample size is still adequate for a multilevel model to perform well (Curran et al., 2010).

Additional covariates added to the model for one child women include age at first birth, expectation prior to first birth, year of first birth, partnership status, and highest qualification attained (Model 3). The operationalisation of each variable is detailed in appendix 1.

\section{USA Sample}

The National Longitudinal Survey of Youth (NLSY) follows a cohort aged 18-22 from 1979, initially yearly, and then every two years from 1994 until 2014 (Bureau of Labor Statistics: U.S. Department of Labor, 2019). The women of this cohort therefore have complete fertility information. Expected family size was asked at every wave through the question: 'Altogether, how many (more) children do you expect to have?'.

Our first model included all women who had at least one child, a censor at second birth for higher parity women, and at least three repeat observations of our outcome within the time 
point of interest (five years before and after birth). 11 observations were dropped as they expected more than ten children which all appeared to be data entry mistakes. This model included 3652 women with 18145 observations (Model 1). The second model used a sample of only one child women with at least three observations in the interval of interest. This sample comprised 1078 women with 5783 observations (Model 2).

Additional covariates included in the model for one child women (please see appendix 2 for more detail) included age at first birth, partnership status, expectation prior to first birth, highest qualification attained, geographical region and ethnicity (Model 3).

\section{Comparability of the Datasets}

The datasets share several overlapping features. For one, they ask about fertility expectations with the same question phrasing. They also share some covariates, such as whether the respondent went on to have a second child, age at first birth, partnership status, and highest qualification attained.

However, there are also differences which hamper comparability. The most important being differences in survey structure and time-period of observation. The USA survey is a cohort study of 14-22 year olds which started in 1979, meaning that all women have now completed their childbearing. By contrast, the UK survey has a household panel structure, with the first survey used here from 1992. This necessitates controlling for the year of first birth in the UK survey, as women of the same age may have been subject to different childbearing norms and environments in the 1990s compared to the 2000s. Further, whilst there is overlap in the period of observation of the two surveys, the UK survey has more recent childbearing recorded. Another comparability issue is that UK sample is smaller than the US sample, meaning the analyses have less statistical power. Finally, not all UK one child women have completed their childbearing, making the identification of final 'one child women' as in the cohort study 
impossible. However, the sample is not heavily biased towards women who will eventually have two children: $56.8 \%$ of the one child women were 45 and over at the time of last observation in the UKHLS. Further, $75 \%$ of the UK one child women were observed for the last time at least 8 years after first birth, and it is unlikely many of these will have a second child after this time point. We also performed a sensitivity analyses with only women who were 45 or older at the last time of observation in the UKHLS and produced similar results to our main findings but with wider confidence intervals (appendix 3). A detailed comparison of the UK and US datasets can also be found in appendix 4.

\section{Results}

In the following section, we begin by describing the characteristics of the different samples in this study, so that we can evaluate how selectivity influences our findings. We then show the trajectories of fertility expectations for one child women in both countries, before comparing them to the trajectories of higher parity women. Finally, we test whether any characteristics of the women are associated with differences in the level (intercept) and change in trajectories (slope) of fertility expectations over time.

\section{Descriptive Analysis}

The characteristics of our four samples (one child women in the UK and US, women with more than one child in the UK and US) are reported in Table 1. One child women in the UK sample are more likely than US one child women to be in partnerships when observed $(17.9 \%$ difference) and are more likely to finish school with a qualification (10\% difference). Whilst the USA and UK have nearly equal share of women with a first birth in their late twenties (2630 ), the rest of the USA one child sample is more skewed towards younger ages ( $<26$ years $)$ at first birth (54.9\%) compared to the UK (19\%). 


\begin{tabular}{|c|c|c|c|c|}
\hline & $\begin{array}{l}\text { UK women with } 1 \text { child } \\
\text { (observation count) }\end{array}$ & $\begin{array}{l}\text { UK women } \\
\text { with 2+ } \\
\text { children } \\
\text { (observation } \\
\text { count) }\end{array}$ & $\begin{array}{l}\text { USA women with } 1 \text { child } \\
\text { (observation count) }\end{array}$ & $\begin{array}{l}\text { USA women with } \\
\text { 2+ children } \\
\text { (observation count) }\end{array}$ \\
\hline $\begin{array}{l}\text { Average number of } \\
\text { observations per individual }\end{array}$ & 3.9 & 3.6 & 5.7 & 5.1 \\
\hline Partnership status & $\mathrm{N}=718$ & $\mathrm{~N}=384$ & $\mathrm{~N}=5782$ & $\mathrm{~N}=12363$ \\
\hline $\begin{array}{l}\text { No partner/spouse } \\
\text { Partner/spouse }\end{array}$ & $\begin{array}{l}181(25.2 \%) \\
537(74.8 \%) \\
\end{array}$ & $\begin{array}{l}113(29.4 \%) \\
271(70.6 \%) \\
\end{array}$ & $\begin{array}{l}2493(43.1 \%) \\
3289(56.9 \%) \\
\end{array}$ & $\begin{array}{l}5266(42.6 \%) \\
7097(57.4 \%) \\
\end{array}$ \\
\hline Education & $\mathrm{N}=718$ & $\mathrm{~N}=384$ & $\mathrm{~N}=5764$ & $\mathrm{~N}=12338$ \\
\hline $\begin{array}{l}\text { Did not finish high school } \\
\text { Finished high school } \\
\text { GCSE or other qualification } \\
\text { A level } \\
\text { Attended college } \\
\text { Completed university }\end{array}$ & $\begin{array}{l}31(4.3 \%) \\
279(38.9 \%) \\
184(25.6 \%) \\
\\
224(31.2 \%) \\
\end{array}$ & $\begin{array}{l}3(0.8 \%) \\
123(32.0 \%) \\
110(28.7 \%) \\
148(38.5 \%) \\
\end{array}$ & $\begin{array}{l}823(14.3 \%) \\
2586(44.9 \%) \\
2355(40.9 \%)\end{array}$ & $\begin{array}{l}2451(19.9 \%) \\
5305(43.0 \%) \\
4582(37.1 \%)\end{array}$ \\
\hline $\begin{array}{l}\text { Age at first birth } \\
\text { Under } 20 \\
21-25 \\
26-30 \\
31-35 \\
36+ \\
\end{array}$ & $\begin{array}{l}\mathrm{N}=718 \\
43(6.0 \%) \\
93(13.0 \%) \\
177(24.7 \%) \\
274(38.2 \%) \\
131(18.3 \%) \\
\end{array}$ & $\begin{array}{l}\mathrm{N}=384 \\
0(0 \%) \\
58(15.1 \%) \\
161(41.9 \%) \\
145(37.8 \%) \\
20(5.2 \%) \\
\end{array}$ & $\begin{array}{l}\mathrm{N}=5782 \\
1202(20.8 \%) \\
1969(34.1 \%) \\
1441(24.9 \%) \\
723(12.5 \%) \\
447(7.7 \%) \\
\end{array}$ & $\begin{array}{l}\mathrm{N}=12363 \\
3491(28.2 \%) \\
5063(41.0 \%) \\
2780(22.5 \%) \\
891(7.2 \%) \\
138(1.1 \%) \\
\end{array}$ \\
\hline Expectation before first birth & $\mathrm{N}=718$ & $\mathrm{~N}=384$ & $\mathrm{~N}=5782$ & $\mathrm{~N}=12363$ \\
\hline $\begin{array}{l}1 \text { or } 0 \\
2 \text { stated at least once } \\
\text { Only observed after first birth }\end{array}$ & $\begin{array}{l}104(14.5 \%) \\
446(62.1 \%) \\
168(23.4 \%) \\
\end{array}$ & $\begin{array}{l}19(5.0 \%) \\
365(95.0 \%) \\
0(0 \%) \\
\end{array}$ & $\begin{array}{l}872(15.1 \%) \\
4620(79.9 \%) \\
290(5.02 \%) \\
\end{array}$ & $\begin{array}{l}796(6.4 \%) \\
11171(90.4 \%) \\
396(3.2 \%) \\
\end{array}$ \\
\hline Ethnicity & & & $\mathrm{N}=5782$ & $\mathrm{~N}=12363$ \\
\hline $\begin{array}{l}\text { Hispanic } \\
\text { Black } \\
\text { Non-hispanic and non-black }\end{array}$ & & & $\begin{array}{l}723(12.5 \%) \\
1363(23.6 \%) \\
3696(63.9 \%) \\
\end{array}$ & $\begin{array}{l}2384(19.3 \%) \\
2970(24.0 \%) \\
7009(56.7 \%) \\
\end{array}$ \\
\hline Geographical region & & & $\mathrm{N}=5727$ & $\mathrm{~N}=12231$ \\
\hline $\begin{array}{l}\text { North East } \\
\text { North Central } \\
\text { South } \\
\text { West } \\
\end{array}$ & & & $\begin{array}{l}1008(17.6 \%) \\
1232(21.5 \%) \\
2409(42.1 \%) \\
1078(18.8 \%) \\
\end{array}$ & $\begin{array}{l}2198(18.0 \%) \\
2904(23.7 \%) \\
4570(38.2 \%) \\
2459(20.1 \%) \\
\end{array}$ \\
\hline Religious affiliation in 1979 & & & $\mathrm{~N}=5747$ & $\mathrm{~N}=12336$ \\
\hline $\begin{array}{l}\text { None } \\
\text { Protestant } \\
\text { Roman Catholic } \\
\text { Jewish } \\
\text { Other } \\
\end{array}$ & & & $\begin{array}{l}549(9.55 \%) \\
2800(48.72 \%) \\
1738(30.24 \%) \\
45(0.78 \%) \\
615(10.7 \%) \\
\end{array}$ & $\begin{array}{l}902(7.3 \%) \\
5562(45.1 \%) \\
4320(35.0 \%) \\
105(0.8 \%) \\
1147(11.7 \%) \\
\end{array}$ \\
\hline Decade of first birth & $\mathrm{N}=718$ & $\mathrm{~N}=384$ & & \\
\hline $\begin{array}{l}1990-1999 \\
2000-2010\end{array}$ & $\begin{array}{l}308(42.9 \%) \\
410(57.1 \%)\end{array}$ & $\begin{array}{l}107(27.9 \%) \\
277(72.1 \%)\end{array}$ & & \\
\hline
\end{tabular}

Table 1: Observation counts and percentages of different model covariates among all mothers and one child women in the USA and UK.

Comparing one child women to mothers of higher parities, one child women appear to be demographically distinct on some characteristics. In both countries they are more likely to be slightly older at first birth, and expect fewer than two children prior to first birth. In the USA they are also more likely to not be Hispanic, Black or Catholic. In the UK, one child women are more likely to be partnered, lower educated and have their first child in the 1990s. 
Question 1: Do one child women experience a decline in fertility expectations after first birth?

The figures in the following sections plot predicted expected family size from five years before to five years after first birth. The first red line illustrates when an individual is two months pregnant, and the second the first birth. Regression results are reported in Table 2, and the unadjusted figures (not adding 1 to the estimates after first birth in order to plot total expected family size) are presented in appendix 5.
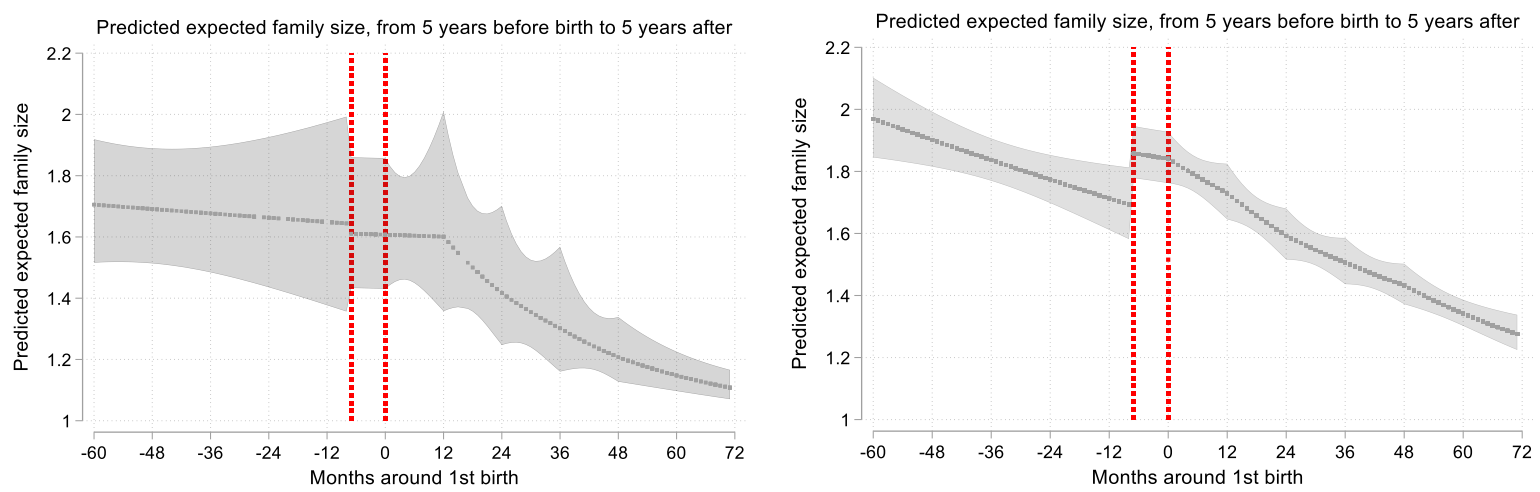

Figure 1: Predicted expected family size from 5 years before to 5 years after first birth in the UK (left) and USA (right) for one child women. Shaded area corresponds to the $95 \%$ confidence interval.

In both the UK (Figure 1, left panel, $n=192$ ) and the USA (Figure 1, right panel, $\mathrm{n}=1078$ ), one child women appear to follow similar trends in their expectations over time. The years from five to one year before birth are marked by a slightly decreasing trend in both contexts: in the UK from 1.7 to 1.65 , and in the USA from 2 to 1.7 . By the time of first birth, one child women are thus expecting on average fewer than the normative ideal family size of two. After this time point the control for being pregnant/having a first child creates a small jump between the prepregnancy period and the period after. It would be disingenuous to not control for pregnancy/having a first child, as the evaluation of total expected family size is fundamentally altered when the individual must expect at least one child. A sharp change from the time-period before is therefore the most accurate way to model this change in evaluation, rather than linking the time periods together which would imply gradual change over time. However, the 
overlapping confidence intervals, particularly in the UK, imply that there is not a significant change in expectations at pregnancy.

In the five years after first birth, a steeper downward trend compared to before first birth can be seen in both contexts, particularly the UK after the child is age 1 . This was confirmed in a simpler analysis with only one spline at pregnancy (appendix 6), which found a significantly steeper regression line in the period after, compared to before, first birth $(p<0.005$ in both countries). During the post-birth period, expectations for one child women drop from 1.6 to 1.1 in the UK, and 1.85 to 1.3 in the USA. The slope of the final spline interval (from four years after birth) was significantly decreasing relative to the angle of the first spline interval (from five years before first birth to pregnancy) in both countries. Although the other intervals were not statistically significant, each spline interval had a coefficient steeper than that of the first interval before birth. This may suggest that there is not enough statistical power to detect change in the shorter (one year) spline intervals given there is a clear overall trend downwards. In the intervals prior to the last, the steepest coefficient in both contexts is in the year when the child is aged one (0.7 in the UK, and 0.84 in the USA). 


\begin{tabular}{|c|c|c|c|c|}
\hline & Meaning & Levels & $\begin{array}{l}\text { UK one child } \\
\text { women }(718 \\
\text { obs, } n=192)\end{array}$ & $\begin{array}{l}\text { USA one child women } \\
(5770 \text { obs, } n=1078)\end{array}$ \\
\hline Constant & Intercept of the model & NA & $1.71 * * *$ & $1.94 * * *$ \\
\hline Time & $\begin{array}{l}\text { Baseline effect per } 12 \\
\text { months }\end{array}$ & $\begin{array}{l}\text { Linear, } 0 \text { is the intercept ( } 5 \text { years } \\
\text { before birth) }\end{array}$ & 0.99 & $0.97 *$ \\
\hline \multirow[t]{2}{*}{$\begin{array}{l}\text { Binary indicator 'not } \\
\text { yet pregnant' }\end{array}$} & \multirow{2}{*}{$\begin{array}{l}\text { Changes in additional } \\
\text { number of children } \\
\text { expected when the } \\
\text { arrival of the first child } \\
\text { is confirmed }\end{array}$} & Time $<-7$ months from birth & Ref & Ref \\
\hline & & Time $=>-7$ months from birth & $0.38 * * *$ & $0.51 * * *$ \\
\hline \multirow{6}{*}{$\begin{array}{l}\text { Time binary } \\
\text { indicator (Splines } \\
\text { after birth) }\end{array}$} & \multirow{6}{*}{$\begin{array}{l}\text { Changes in } \\
\text { expectation at different } \\
\text { ages of the first child }\end{array}$} & Child < 0: & Ref & Ref \\
\hline & & Child aged 0-12 months: & 1.00 & 0.90 \\
\hline & & Child aged 12-24 months: & 0.70 & $0.84 \dagger$ \\
\hline & & Child aged 24-36 months: & 0.73 & 0.88 \\
\hline & & Child aged 36-48 months: & 0.69 & 0.88 \\
\hline & & Child aged 48-50 months: & $0.72 * * *$ & $0.81 * * *$ \\
\hline
\end{tabular}

Table 2: Incidence rate ratios for one child women in the UK (column 4) and USA (column 5). Column 1 lists the variable, column 2 the variables meaning, and column 3 the categories of the variable.

$* * * \mathrm{p}<0.005, * * \mathrm{p}<0.01, * \mathrm{p}<0.05, \dagger \mathrm{p}<0.1$

Question 2: Do one child women experience a decline in expectations after first birth not seen for higher parity women?

Here we fit a model for UK ( $n=303$, average number of observations per person=3.6) and US $(n=3652$, average number of observations per person=5.9) mothers, stratifying by parity and including a censor for higher parity women at second birth (Table 3). The censor means that estimates of expected family size are comparable in the period after first birth between one child and higher parity women. Note, though, that it means that the sample of higher parity women becomes more selective as time passes since first birth, as women increasingly drop out of the sample because of their second birth. The censored higher parity sample have a different trajectory over time compared to one child women in both contexts. The higher parity sample begin with slightly higher expectations, and remain more stable in those expectations (if not increasing in the UK) in the period before first birth. After first birth, the higher parity women follow a downwards trajectory, increasingly similar to one child women's trajectory, as the higher parity sample becomes more selective. The p-value for 
difference in slope (the interaction between time and the two groups) is highly significant in

both contexts $(\mathrm{p}<0.005)$.
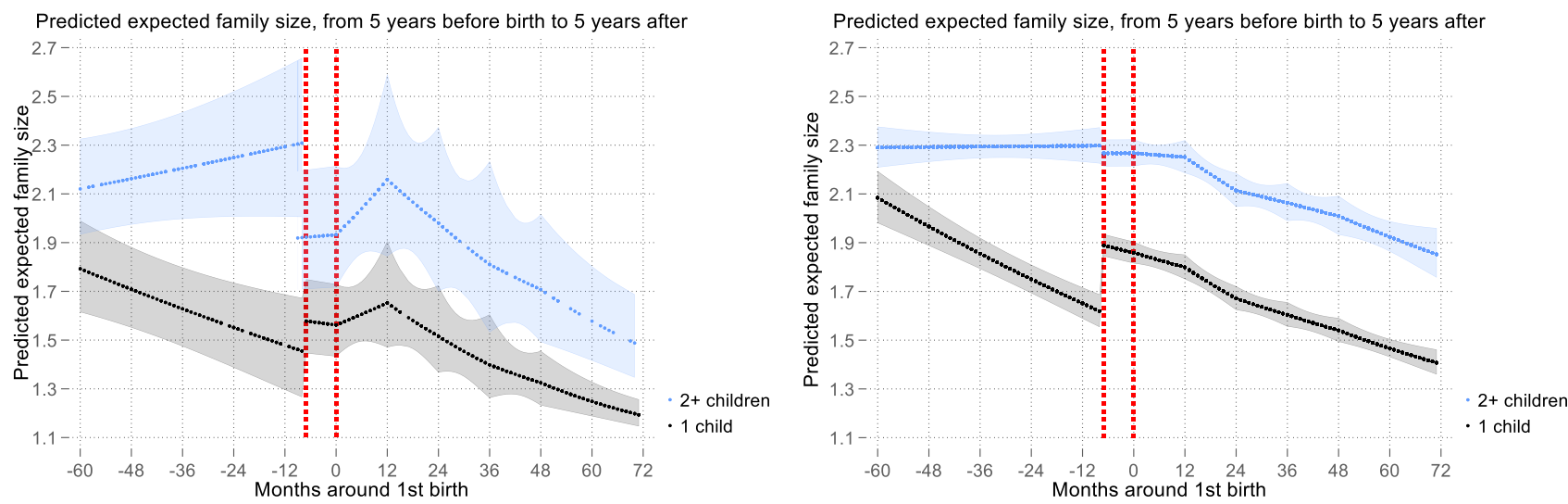

Figure 2: Predicted expected family size (modelled with random intercept and random slope) from 5 years before to 5 years after first birth in the UK (left) and USA (right) for all mothers, stratified by parity ( 1 child and 2 or more) and including a censor at second birth. Shaded areas are the $95 \%$ confidence interval. The colour of the area corresponds to the line that they are calculated for.

\begin{tabular}{|c|c|c|c|c|}
\hline & Meaning & Levels & $\begin{array}{l}\text { UK all mothers } \\
(1102 \text { obs, } \\
\text { n=303) }\end{array}$ & $\begin{array}{l}\text { USA all mothers } \\
(18108 \text { obs, } n=3652)\end{array}$ \\
\hline Constant & Intercept of the model & NA & $1.79 * * *$ & $2.07 * * *$ \\
\hline Time & Baseline effect per month & Linear. 0 is the month of birth & $0.95 * * *$ & $0.95 * * *$ \\
\hline \multirow{3}{*}{$\begin{array}{l}\text { Binary indicator } \\
\text { 'not yet } \\
\text { pregnant' }\end{array}$} & \multirow{3}{*}{$\begin{array}{l}\text { Changes in additional } \\
\text { number of children } \\
\text { expected when the arrival } \\
\text { of the first child is } \\
\text { confirmed }\end{array}$} & & & \\
\hline & & Time < -7 months from birth & Ref & Ref \\
\hline & & Time $=>-7$ months from birth & $0.40 * * *$ & $0.55 * * *$ \\
\hline \multirow{6}{*}{$\begin{array}{l}\text { Time binary } \\
\text { indicator } \\
\text { (Splines after } \\
\text { birth) }\end{array}$} & \multirow{6}{*}{$\begin{array}{l}\text { Changes in expectation at } \\
\text { different ages of the first } \\
\text { child }\end{array}$} & Child <0: & Ref & Ref \\
\hline & & Child aged 0-12 months: & 1.22 & 0.99 \\
\hline & & Child aged 12-24 months: & 0.83 & $0.89 *$ \\
\hline & & Child aged 24-36 months: & 0.81 & 0.95 \\
\hline & & Child aged 36-48 months: & 0.86 & 0.95 \\
\hline & & Child aged $48-50$ months: & $0.80 * * *$ & $0.91 *$ \\
\hline \multirow{2}{*}{$\begin{array}{l}\text { More than one } \\
\text { child }\end{array}$} & \multirow{2}{*}{$\begin{array}{l}\text { Whether mother eventually } \\
\text { had more than one child or } \\
\text { not }\end{array}$} & No & Ref & Ref \\
\hline & & Yes & $1.18 *$ & $1.1 * * *$ \\
\hline \multirow{2}{*}{$\begin{array}{l}\text { More than one } \\
\text { child x Time }\end{array}$} & \multirow{2}{*}{$\begin{array}{l}\text { Interaction of the two } \\
\text { groups (one child vs higher } \\
\text { parity women) } \\
\text { expectations over time }\end{array}$} & No & Ref & Ref \\
\hline & & Yes & $1.07^{* * *}$ & $1.06^{* * * *}$ \\
\hline
\end{tabular}

Table 3: Incidence rate ratios for all mothers in the UK (column 4) and USA (column 5). Column 1 lists the variable, column 2 the variables meaning, and column 3 the categories of the variable. Control for final parity is included and a censor at second birth. ${ }^{* * *} \mathrm{p}<0.005,{ }^{* *} \mathrm{p}<0.01,{ }^{*} \mathrm{p}<0.05, \dagger \mathrm{p}<0.1$ 
Question 3: Are there any characteristics of one child women which are particularly associated with changes in trajectories over time?

Finally, we test for differences in intercept (mean differences in expectations) and slope (difference in overall trajectories) of expectations by different covariates known to be associated with fertility expectations and outcomes (Table 4). In the univariate analysis for the UK (Appendix 7) and the USA (Appendix 8), age at first birth was strongly predictive of differences in trajectories (Figure 3). There were minimal differences in starting point (five years before birth, the intercept) in the UK, however in the USA we found evidence that the oldest two age groups expect fewer children at this time point $(\mathrm{p}<0.05$ for $31-35$, $\mathrm{p}<0.005$ for $36+)$. There was much clearer statistical evidence in both contexts of variation across time in the two groups. Compared to the youngest age group, each age group sees a steeper downwards trajectory over time. The overall trend observed therefore, is steeper revisions before first birth for the older age groups, and after first birth for the younger age groups.
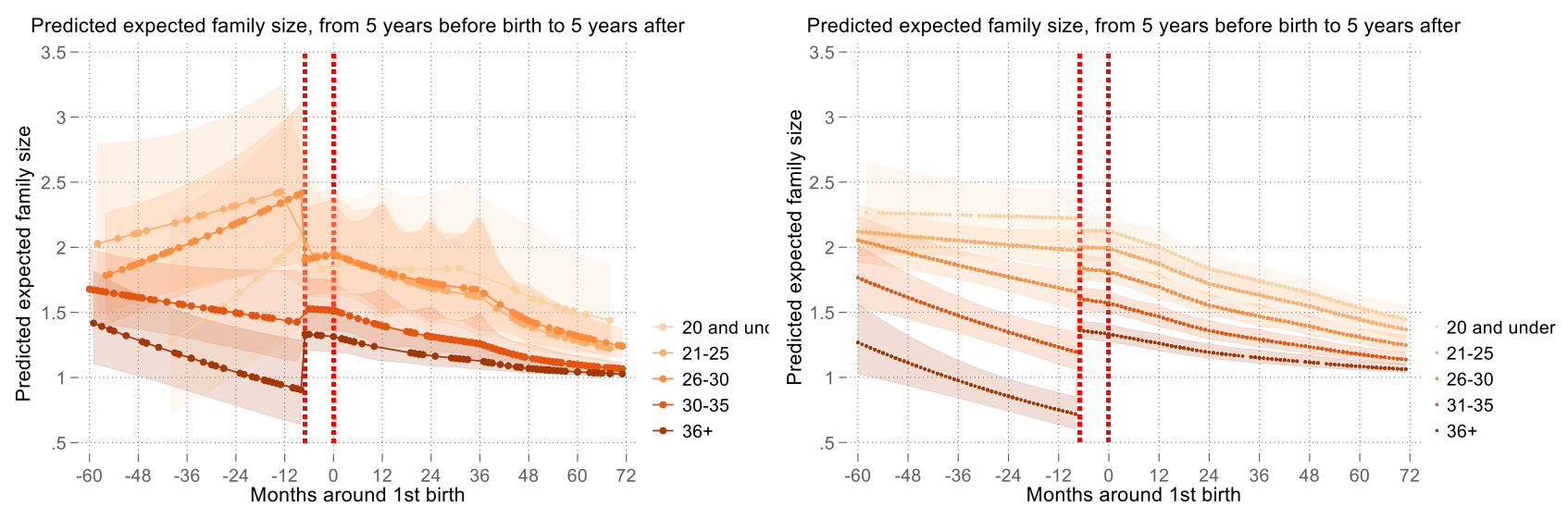

Figure 3: Predicted expected family size (modelled with random intercept and random slope) from 5 years before to 5 years after first birth in the UK (left) and USA (right) for one child women, stratified by age of first birth. Shaded areas are $95 \%$ confidence intervals. The colour of the shaded area corresponds to the colour of the line it is calculated for. 

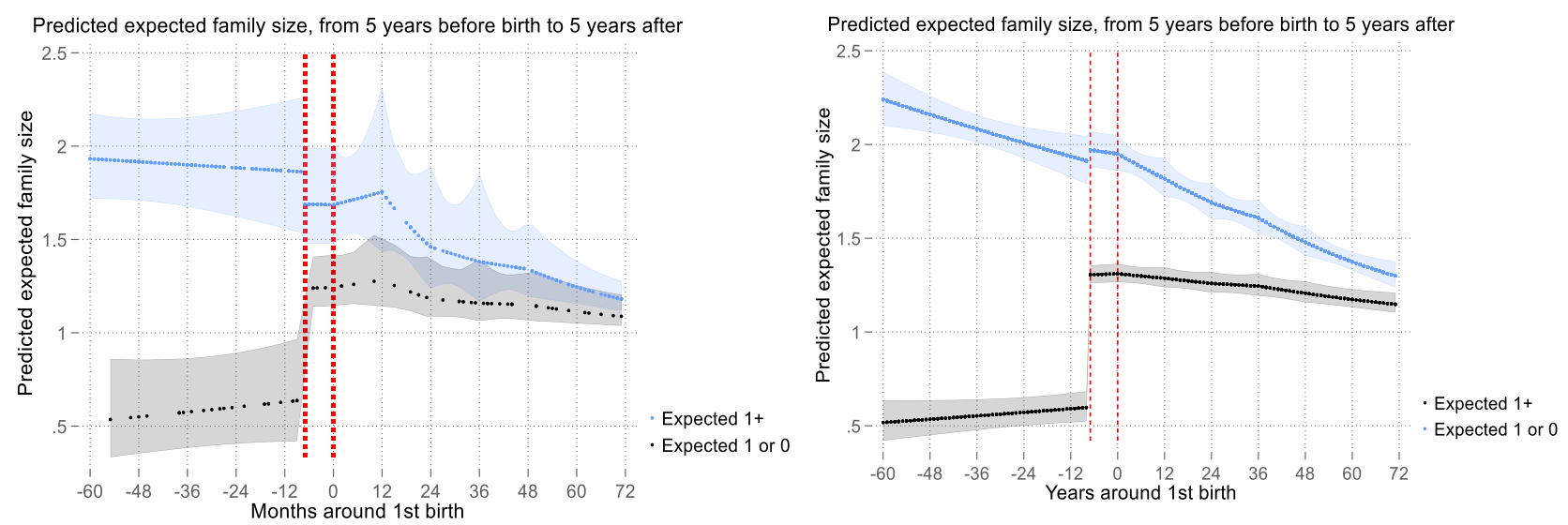

Figure 4: Predicted expected family size (modelled with random slope and random intercept) from 5 years before to 5 years after first birth in the UK for one child women, stratified by expectations prior to first birth. Shaded areas are the $95 \%$ confidence interval. The colour of the shaded area corresponds to the line it was calculated for.

We also explored whether expectations prior to first birth (either expecting two at least once, or consistently expecting fewer than two prior to first birth, Figure 4) were predictive of differences in intercept and slope. By nature of the dummy variable, differences in intercept are to be expected $(\mathrm{p}<0.005$ in both countries). In the US there was also a significant difference in slope between the two groups (i.e. the interaction between the two expectations groups with time), but not in the UK. The trend seen is that women expecting fewer than two children are much more stable in their expectations before and after pregnancy (aside for the jump accounting for first birth). However, women who expect two or more children before first birth show a general decreasing trend over time.

In the USA, we also stratified the analysis by geographical region (plot in appendix 9). We included this covariate as we predicted it should not influence the evolution of expectations over time. We found no statistically significant difference in the intercept at five years before birth between the groups, or a significant interaction with time (differences in slope). Plotting predicted expectations over time, the Southern region does appear to be less pronatal than the other regions, although confidence intervals overlap. Together the evidence suggests that the experience of one child women in their expectations over time does not vary by region, as we 
predicted. This further supports our argument of a similar experience for one child women geographically, both within and between the countries in this analysis.

In the USA neither education ethnicity, partnership status nor religion produced significant differences in slope or intercept among one child women in the univariate analysis. In the UK, partnership status, education, and year of first birth (cohort control) were not significant in the univariate analysis. All reported trends in intercept and slope across demographic groups in the two countries held when included in the full model of all covariates (Table 4). 


\begin{tabular}{|c|c|c|c|c|}
\hline & Meaning & Levels & $\begin{array}{l}\text { UK one child } \\
\text { women }(o b s=550, \\
\text { n=142) }\end{array}$ & $\begin{array}{l}\text { USA one child women } \\
\text { (obs }=5379, n=988)\end{array}$ \\
\hline Constant & Intercept of the model & NA & $2.15 * * *$ & $2.58 * * *$ \\
\hline Time & Baseline effect per month & Linear, 0 is the month of birth & 1.05 & 0.98 \\
\hline \multirow{2}{*}{$\begin{array}{l}\text { Binary indicator } \\
\text { 'not yet pregnant' }\end{array}$} & \multirow{2}{*}{$\begin{array}{l}\text { Changes in additional number of } \\
\text { children expected when the arrival } \\
\text { of the first child is confirmed }\end{array}$} & Time $<-7$ months from birth & Ref & Ref \\
\hline & & Time => -7 months from birth & $0.36 * * *$ & $0.50 * * *$ \\
\hline \multirow{6}{*}{$\begin{array}{l}\text { Time binary } \\
\text { indicator (Splines } \\
\text { after birth) }\end{array}$} & \multirow{6}{*}{$\begin{array}{l}\text { Changes in expectation at different } \\
\text { ages of the first child }\end{array}$} & Child <0: & Ref & Ref \\
\hline & & Child aged 0-12 months: & 0.89 & 0.88 \\
\hline & & Child aged 12-24 months: & 0.68 & 0.88 \\
\hline & & Child aged 24-36 months: & 0.97 & 0.90 \\
\hline & & Child aged 36-48 months: & 0.64 & 0.83 \\
\hline & & Child aged 48-52 months: & $0.65 * * *$ & $0.83 *$ \\
\hline \multirow[t]{2}{*}{ Partnership status } & \multirow[t]{2}{*}{ Whether respondent has a partner } & No & Ref & Ref \\
\hline & & Yes & 0.86 & 1.01 \\
\hline \multirow[t]{6}{*}{ Education } & \multirow[t]{6}{*}{ Highest educational attainment } & GCSE or other qualification & Ref & \\
\hline & & Finished high school & & Ref \\
\hline & & Did not finish high school & 0.75 & 0.98 \\
\hline & & Attended college & & 1.06 \\
\hline & & Completed University & 1.08 & \\
\hline & & A level & 0.94 & \\
\hline \multirow[t]{5}{*}{ Age at first birth } & & Under 20 & $0.43^{*}$ & Ref \\
\hline & & $21-25$ & Ref & 0.90 \\
\hline & & $26-30$ & 0.95 & 0.86 \\
\hline & & $31-35$ & 0.91 & 0.84 \\
\hline & & $36+$ & 0.83 & $0.79 \dagger$ \\
\hline \multirow{5}{*}{$\begin{array}{l}\text { Age at first birth } x \\
\text { Time }\end{array}$} & & Under 20 & $1.19^{*}$ & Ref \\
\hline & & $21-25$ & Ref & 1.00 \\
\hline & & $26-30$ & 1.04 & $0.97 \dagger$ \\
\hline & & $31-35$ & 0.95 & $0.93 * * *$ \\
\hline & & $36+$ & $0.89^{*}$ & $0.88 * * *$ \\
\hline \multirow[t]{2}{*}{$\begin{array}{l}\text { Expectations } \\
\text { before first birth }\end{array}$} & \multirow[t]{2}{*}{$\begin{array}{l}\text { Binary indicator of whether } 2 \\
\text { children expected at least once } \\
\text { before first birth }\end{array}$} & Yes & Ref & Ref \\
\hline & & No & $0.36 * * *$ & $0.24 * * *$ \\
\hline \multirow{2}{*}{$\begin{array}{l}\text { Expectations } \\
\text { before first birth } x \\
\text { Time }\end{array}$} & & Yes & & Ref \\
\hline & & No & & $1.10 * * *$ \\
\hline \multirow{2}{*}{$\begin{array}{l}\text { Decade of first } \\
\text { birth }\end{array}$} & & $1990-1999$ & Ref & \\
\hline & & $2000-2010$ & 1.06 & \\
\hline \multirow[t]{3}{*}{ Ethnic group } & & Hispanic & & Ref \\
\hline & & Black & & 0.99 \\
\hline & & Not black or hispanic & & 0.98 \\
\hline \multirow{4}{*}{$\begin{array}{l}\text { Geographic } \\
\text { Region }\end{array}$} & & West & & Ref \\
\hline & & North East & & 1.01 \\
\hline & & North Central & & 0.98 \\
\hline & & South & & 0.94 \\
\hline \multirow{5}{*}{$\begin{array}{l}\text { Religious } \\
\text { affiliation in } 1979\end{array}$} & & No religion & & Ref \\
\hline & & Protestant denominations & & 0.98 \\
\hline & & Roman Catholic & & 1.08 \\
\hline & & Jewish & & 1.00 \\
\hline & & Other & & 1.10 \\
\hline
\end{tabular}

Table 4: Incidence rate ratios for one child women in the UK (column 4) and USA (column 5), including socio-demographic covariates. Column 1 lists the variable, column 2 the variables meaning, and column 3 the categories of the variable. $* * *$ $\mathrm{p}<0.005, * * \mathrm{p}<0.01, * \mathrm{p}<0.05, \dagger \mathrm{p}<0.1$ 


\section{Discussion}

The existence of a fertility gap in high-income countries suggests that individuals are facing obstacles to meeting their childbearing goals. However, this aggregate measure hides the variability of personal expectations over the life course. This paper aimed to dissect whether and how childbearing expectations changed for UK and US one child women. In doing so, we explored how one child women contribute to the fertility gap (i.e. do they always intend to have one child, or do they revise downwards over time?). One child women are an interesting group to focus on in relation to the fertility gap, as whilst they become parents, they have fewer than the normative two. We hypothesised that the time around first birth may act as a catalyst for changing expectations, in a way not experienced by women who have more than one child. Further, we use the comparison between the USA, the UK and US regions to assess the homogeneity of one child women's expectation trajectories across contexts and whether demographic characteristics are associated with variation in those trajectories.

Firstly, we explored whether one child women experience a decline in fertility expectations after first birth in both the US and UK. Overall, the pattern observed in the trajectories of one child women is broadly similar across contexts: stability, but a slight decrease in expectations before first birth, followed by a marked decrease in expectations after first birth towards one. Therefore, we broadly find evidence supporting the hypothesis that one child women's expectations decrease close to one after first birth across contexts, but with the caveat that they are already starting to revise their expectations away from an average of two before first birth. We also did not find any particularly steep change within a given year, although the steepest drop in both countries occurred when the child was between one and two. The similarity of changing expectation trajectories over time for one child women suggests that their contribution to the fertility gap lies in revising expectations from an average of two to one child over time. The differences between countries and regions in pronatalism are likely 
to explained by different underlying demographic characteristics (e.g. the USA has a younger childbearing profile for one child women than the UK), time period of observation (the UK observes slightly later childbearing, mostly in the early 2000s) and cultural variation in the strength of the two child family norm.

Our second question was whether the trajectory of fertility expectations differs over time for one child women compared to higher parity women. We found a clear divergence in the lead up to first birth: higher parity women maintain expectations above two prior to first birth, whereas the expectations of one child women begin to decrease. After first birth, the shape of the trajectories in each group looks more similar as the sample for higher parity women becomes more selective because of censoring, resulting in the regression line being increasingly determined by the one child women. However, it is noteworthy that whilst the members of the higher parity group are decreasing their expectations at five years after birth to 1.9 in the US and 1.5 in the UK, the one child group have decreased their expectations to much closer to one (1.4 in the US and 1.2 in the UK). Thus, whilst the censored higher parity sample follow a similar trajectory after first birth to one child women, they are still more pronatal.

Lastly, we tested whether any characteristics of one child women were associated with differences in expectation trajectories over time. In the US, we found minimal differences between education, ethnic, or religious groups in trajectories over time. Selectivity may have played a role; indeed, the one-child sample was biased (in comparison to the higher parity women) towards non-black and non-hispanic women, those that attended college, and those that are Protestant or non-religious. These differences between one child and higher parity women are in line with known differences in fertility in the USA: Latina women, Catholic women and women who did not finish high school are known to have higher fertility, and are thus less likely to only have one child. 
Neither education nor partnership status were predictive of expectation trajectories for UK one child women. This would appear to confirm that sample selectivity is diminishing the variation in trajectories between women, given that partnership and education were important predictors in expectations in previous studies (Berrington, 2004). However, the model may not have detected differences because the small sample size will have decreased statistical power. The only significant covariates in both countries were age at first birth and expectations prior to first birth.

We restricted our analysis to only include more stable characteristics as explanatory factors for variation in trajectories over time. This is because including factors in our model that change around first birth (e.g. pregnancy experiences, household division of labour and labour market activity) would require more advanced statistical methodologies to disentangle causality during a time of many simultaneous changes. However, these variables are likely to have the most explanatory power for why one child women are revising their expectations more steeply after first birth. Nonetheless, we can draw on the previous literature and our analysis for potential explanations. Ní Bhrolcháin and Beaujouan (2011), for example have noted one child women in the UK are more uncertain about their fertility intentions than other women. This may be a reason why expectations after birth are more susceptible to change in response to first birth and associated changes for one child women, compared to higher parity women. The selectivity of our analytical sample also offers potential explanations for why one child women are revising their expectations downwards. For example, as the one child USA women are less religious, they may be less likely to experience strong pronatal social norms, making it easier for them to revise their expectations downwards. This would fit with previous findings that religious women have more stable fertility ideals (Ray et al., 2018). The high education level among US one child women may also be indicative that one child women are delaying childbearing relative to those who complete education earlier. This is 
supported by the skew of the sample to older ages at first birth (relative to the higher parity sample). Delaying first childbirth results in a decreased likelihood of meeting expectations for large families, and thus more variability in fertility plans over time (Heiland et al., 2008; Liefbroer, 2009).

There are various limitations to our approach that should be acknowledged. First, is that we do not statistically compare the two countries because of comparability issues, such as the smaller sample size of the UK data, and that a small proportion of UK women will eventually have a second child. These issues mean that the UK dataset can only be used tentatively in descriptive comparisons to the US data. Second, there are inherent restrictions to our statistical model about how the trajectories are predicted. For example, including an interaction of a covariate over time allows the trajectory to vary between covariate groups, but it retains the overall angle of the regression line. This presupposes that the angle of the regression line at each spline is the same for each of the groups. Finally, we chose to restrict our comparison to two countries with similar fertility profiles. However, this means that our findings are not necessarily generalisable to other low-fertility settings.

Nonetheless, we argue that our analytical strategy presents a clearer picture of change in expectations around first birth compared to previous studies exploring the effect of births on expectations. First, a Poisson specification is used, rather than a linear one to better account for the discrete nature of childbearing expectations. Secondly, by focusing exclusively on one child women, as opposed to all women over time, we eliminate the impact of progression to higher parities on expectations over time. Including women of all parities would make it difficult to identify those who are revising down over time, amongst those who are raising their expectations in line with the number of children they have. Identifying women that adjust their expectations downwards over time is vital for improving our explanation of the fertility gap, where individuals appear to not have as many children as they say they want. 
Our paper finds that revisions in fertility expectations for one child women fall close to one child in the 5 years after, not before, birth. Further, steeper revisions after first birth suggest that becoming a parent does affect expectations negatively for one child women, an area that requires further causal investigation. Such investigations would be benefitted by data collection, including qualitative work, asking about changing expectations in the years directly after first birth when we identified the most change. To conclude, this analysis is an important first step in disentangling and explaining the fertility gap persists in the UK and USA: we find expectations change after 'expecting' for one child women. 


\section{References}

Albertini, M., \& Brini, E. (2020). I've changed my mind. The intentions to be childless, their stability and realisation. European Societies, O(0), 1-42. https://doi.org/10.1080/14616696.2020.1764997

Bachrach, C. A., \& Morgan, S. P. (2013). A Cognitive-Social Model of Fertility Intentions. Population and Development Review, 39(3), 459-485. https://doi.org/10.1111/j.17284457.2013.00612.x

Baxter, J., Hewitt, B., \& Haynes, M. (2008). Life Course transitions and housework: Marriage, parenthood, and time on housework. Journal of Marriage and Family, 70(2). https://doi.org/10.1111/j.1741-3737.2008.00479.x

Beaujouan, É., \& Berghammer, C. (2019). The Gap Between Lifetime Fertility Intentions and Completed Fertility in Europe and the United States: A Cohort Approach. Population Research and Policy Review, 38(4), 507-535. https://doi.org/10.1007/s11113-019-09516-3

Berrington, A. (2004). Perpetual postponers? Women's, men's and couple's fertility intentions and subsequent fertility behaviour. Population Trends, 117, 9-19. https://doi.org/10.2307/2137845

Berrington, A., Hu, Y., Smith, P. W. F., \& Sturgis, P. (2007). A graphical chain model for reciprocal relationships between women's gender role attitudes and labour force participation. Journal of the Royal Statistical Society: Series A (Statistics in Society), O(0), 071029094155002-??? https://doi.org/10.1111/j.1467-985X.2007.00510.x

Berrington, A., \& Pattaro, S. (2014). Educational differences in fertility desires, intentions and behaviour: A life course perspective. Advances in Life Course Research, 21, 10-27. https://doi.org/10.1016/j.alcr.2013.12.003

Berrington, A., Stone, J., \& Beaujouan, E. (2015). Educational differences in timing and quantum of childbearing in britain: A study of cohorts born 1940-1969. Demographic Research, 33(1), 733 764. https://doi.org/10.4054/DemRes.2015.33.26

Billari, F., \& Kohler, H.-P. (2004). Patterns of low and lowest-low fertility in Europe. Population Studies, 58(2), 161-176. https://doi.org/10.1080/0032472042000213695

Bongaarts, J. (2001). Fertility and reproductive preferences in post-transitional societies. Population and Development Review, 27(2001), 260-281. https://doi.org/10.2307/3115260

Bureau of Labor Statistics: U.S. Department of Labor. (2019). National Longitudinal Survey of Youth 1979 cohort, 1979-2016 (rounds 1-27). Produced and distributed by the Center for Human Resource Research (CHRR), The Ohio State University. Columbus, OH.

Campolo, M. G., Pino, A. Di, \& Rizzi, E. L. (2020). The labour division of Italian couples after a birth: assessing the effect of unobserved heterogeneity. Journal of Population Research, 37, 107-137. https://doi.org/10.1007/s12546-020-09241-1

Coleman, D. A., \& Dubuc, S. (2010). The fertility of ethnic minorities in the UK. Population Studies, 64(1), 19-41. https://doi.org/10.1080/00324720903391201

Curran, P. J., Obeidat, K., \& Losardo, D. (2010). Twelve frequently asked questions about growth curve modeling. Journal of Cognition and Development, 11(2), 121-136. https://doi.org/10.1080/15248371003699969

DeRose, L. F., Goldscheider, F., Brito, J. R., Salazar-Arango, A., Corcuera, P., Corcuera, P. J., \& Gas-Aixendri, M. (2019). Are Children Barriers to the Gender Revolution? International Comparisons. European Journal of Population, 1-35. https://doi.org/10.1007/s10680-01809515-8

Dey, I., \& Wasoff, F. (2010). Another child? fertility ideals, resources and opportunities. Population 
Research and Policy Review, 29(6), 921-940. https://doi.org/10.1007/s11113-009-9174-1

Esping-Andersen, G. (1990). The Three Worlds of Welfare Capitalism. Cambridge: Polity Press.

Evertsson, M. (2013). The importance of work: Changing work commitment following the transition to motherhood. Acta Sociologica, 56(2), 139-153. https://doi.org/10.1177/0001699312466177

Fiori, F., Graham, E., \& Feng, Z. (2014). Geographical variations in fertility and transition to second and third birth in Britain. Advances in Life Course Research, 21, 149-167. https://doi.org/10.1016/j.alcr.2013.11.004

Fiori, F., Rinesi, F., \& Graham, E. (2017). Choosing to Remain Childless? A Comparative Study of Fertility Intentions Among Women and Men in Italy and Britain Framing these differences in fertility. European Journal of Population, 33, 319-350. https://doi.org/10.1007/s10680-0169404-2

Frejka, T. (2008). Overview Chapter 2: Parity distribution and completed family size in Europe: Incipient decline of the two-child family model? Demographic Research, 19(4), 47-72. https://doi.org/10.4054/DemRes.2008.19.4

Frejka, T., \& Gietel-Basten, S. (2016). Fertility and Family Policies in Central and Eastern Europe after 1990. Comparative Population Studies, 41(1). https://doi.org/10.12765/CPOS-2016-03EN

Frejka, T., \& Sardon, J.-P. (2007). Cohort birth order, parity progression ratio and parity distribution trends in developed countries. Demographic Research, 16, 315-374. https://doi.org/10.4054/DemRes.2007.16.11

Gemmill, A. (2019). From Some to None? Fertility Expectation Dynamics of Permanently Childless Women. Demography, 56(1), 129-149. https://doi.org/10.1007/s13524-018-0739-7

Gemmill, A., \& Hartnett, C. S. (2020). Demographic drivers of the post-recessionary fertility decline and the future of U.S. fertility.

Gisser, R., Lutz, W., \& Munz, R. (1985). Kinderwunsch und Kinderzahl. In R. Munz (Ed.), Leben mit Kindern. Wunsch und Wirklichkeit . (pp. 33-94). Wien: Franz Deuticke.

Gray, E., Evans, A., \& Reimondos, A. (2013). Childbearing desires of childless men and women: When are goals adjusted? Advances in Life Course Research, 18(2), 141-149. https://doi.org/10.1016/J.ALCR.2012.09.003

Guzzo, K. B., \& Schweizer, V. (2020). Number of Children to Women Aged 40-44, 1980-2018. Family Profiles FP-20-04. Retrieved from https://www.bgsu.edu/ncfmr/resources/data/familyprofiles/guzzo-schweizer-number-children-women-40-44-1980-2018-fp-20-04.html

Harknett, K., \& Hartnett, C. S. (2014). The gap between births intended and births achieved in 22 European countries, 2004-07. Population Studies, 68(3), 265-282. https://doi.org/10.1080/00324728.2014.899612

Hayford, S. R. (2009). The Evolution of Fertility Expectations Over the Life Course. Demography, 46(4), 765-783. https://doi.org/10.1353/dem.0.0073

Heiland, F., Prskawetz, A., \& Sanderson, W. C. (2008). Are Individuals' Desired Family Sizes Stable? Evidence from West German Panel Data. Eur J Population, 24, 129-156. https://doi.org/10.1007/s10680-008-9162-x

Hellstrand, J., Nisén, J., Miranda, V., Fallesen, P., Dommermuth, L., \& Myrskylä, M. (2020). Not just later, but fewer: Novel trends in cohort fertility in the Nordic countries. https://doi.org/10.4054/MPIDR-WP-2020-007

Human Fertility Database. (2020). Retrieved from www.humanfertility.org 
Iacovou, M., \& Tavares, L. P. (2011). Yearning, Learning, and Conceding: Reasons Men and Women Change Their Childbearing Intentions. Population and Development Review, 37(1), 89-123. https://doi.org/10.1111/j.1728-4457.2011.00391.x

Kühhirt, M. (2012). Childbirth and the Long-Term Division of Labour within Couples: How do Substitution, Bargaining Power, and Norms affect Parents' Time Allocation in West Germany? European Sociological Review, 28(5), 565-582. https://doi.org/10.1093/ESR/JCR026

Liefbroer, A. C. (2009). Changes in family size intentions across young adulthood: A life-course perspective. European Journal of Population, 25(4), 363-386. https://doi.org/10.1007/s10680008-9173-7

Luppi, F., \& Mencarini, L. (2018). Parents' subjective well-being after their first child and declining fertility expectations. Demographic Research, 39(1), 285-314. https://doi.org/10.4054/DemRes.2018.39.9

Lutz, W. (2007). The future of human reproduction: will birth rates recover or continue to fall. Ageing Horizons, 7(7), 15-21. Retrieved from http://dev.ageing.ox.ac.uk/system/files/ageing_horizons_7_lutz_fd.pdf

Maximova, K., \& Quesnel-Vallée, A. (2009). Mental health consequences of unintended childlessness and unplanned births: Gender differences and life course dynamics. Social Science and Medicine, 68(5), 850-857. https://doi.org/10.1016/j.socscimed.2008.11.012

Miller, W. B. (2011). Differences between fertility desires and intentions: implications for theory, research and policy. Vienna Yearbook of Population Research, 9, 75-98. https://doi.org/10.1553/populationyearbook2011s75

Miller, W. B., \& Pasta, D. J. (1995). How does childbearing affect fertility motivations and desires? Social Biology, 42(3-4), 185-198. https://doi.org/10.1080/19485565.1995.9988900

Mitchell, D., \& Gray, E. (2007). Declining fertility: Intentions, attitudes and aspirations. Journal of Sociology, 43(1), 23-44. https://doi.org/10.1177/1440783307073933

Morgan, S. P., \& Rackin, H. (2010). The correspondence between fertility intentions and behavior in the United States. Population and Development Review, 36(1), 91-118. https://doi.org/10.1111/j.1728-4457.2010.00319.x

Myers, S., Burger, O., \& Johns, S. E. (2016). Postnatal depression and reproductive success in modern, low-fertility contexts. Evolution, Medicine, and Public Health, 2016(1), 71-84. https://doi.org/10.1093/emph/eow003

Mynarska, M., Matysiak, A., Rybińska, A., Tocchioni, V., \& Vignoli, D. (2015). Diverse paths into childlessness over the life course. Advances in Life Course Research, 25. https://doi.org/10.1016/j.alcr.2015.05.003

Ní Bhrolcháin, M., \& Beaujouan, É. (2011). Uncertainty in fertility intentions in Britain, 1979-2007. Vienna Yearbook of Population Research, 9(1), 99-129.

https://doi.org/10.1553/populationyearbook2011s99

Ní Bhrolcháin, M., Beaujouan, E., \& Berrington, A. (2010). Stability and change in fertility intentions in Britain, 1991-2007. Population Trends, (141), 10-32. https://doi.org/10.1057/pt.2010.19

ONS. (2019). Childbearing for Women Born in Different Years, England and Wales: 2018. Retrieved from http://www.ons.gov.uk/ons/rel/fertility-analysis/childbearing-for-women-born-in-differentyears/2013/stb-cohort-fertility-2013.html

Philipov, D. (2009). Fertility intentions and outcomes: The role of policies to close the gap. European Journal of Population, 25(4), 355-361. https://doi.org/10.1007/s10680-009-9202-1

Philipov, D., \& Bernardi, L. (2011). Concepts and Operationalisation of Reproductive Decisions 
Implementation in Austria, Germany and Switzerland. Comparative Population Studies, 36(23), 531-572. https://doi.org/10.4232/10.CPoS-2011-14en

Quesnel-Vallee, A., \& Morgan, S. P. (2003). Missing the Target ? Correspondence of Fertility Intentions and Behavior in the U . S . Population Research and Policy Review, 22(5), 497-525.

Rackin, H. M., \& Bachrach, C. A. (2016). Assessing the Predictive Value of Fertility Expectations Through a Cognitive-Social Model. Population Research and Policy Review, 35(4), 527-551. https://doi.org/10.1007/s11113-016-9395-z

Ray, C., Harcey, S., Greil, A., Tiemeyer, S., \& McQuillan, J. (2018). Stability and change in personal fertility ideals among U.S. women in heterosexual relationships. Demographic Research, 39, 459-486. https://doi.org/10.4054/DemRes.2018.39.16

Rendall, M., Couet, C., Lappegard, T., Robert-Bobée, I., Rønsen, M., \& Smallwood, S. (2005). First births by age and education in Britain, France and Norway. Population Trends, (121), 27-34.

Rybinska, A., \& Morgan, S. P. (2019). Childless Expectations and Childlessness Over the Life Course. Social Forces, 97(4), 1571-1602. https://doi.org/10.1093/sf/soy098

Shkolnikov, V. M., Andreev, E. M., Houle, R., \& Vaupel, J. W. (2007). The Concentration of Reproduction in Cohorts of Women in Europe and the United States. Population and Development Review, 33(1), 67-100. https://doi.org/10.1111/j.1728-4457.2007.00159.x

Sigle-Rushton, W. (2008). England and Wales: Stable fertility and pronounced social status differences. Demographic Research, 19(15), 455-492. https://doi.org/10.4054/DemRes.2008.19.15

Singh, S., Sedgh, G., \& Hussain, R. (2010). Unintended Pregnancy: Worldwide Levels, Trends and Outcomes. Studies in Family Planning, 41(4), 241-250. Retrieved from http://mpts101.org/docs/SinghSFP-UnintendedPregnancy.pdf

Smallwood, S. (2002). New estimates of trends in births by birth order in England and Wales. Population Trends, (108), 32-48.

Smallwood, S., \& Jefferies, J. (2003). Family building intentions in England and Wales: trends, outcomes and interpretations. Population Trends, 15-28.

Testa, M. R. (2012). Family Sizes in Europe: Evidence from the 2011 Eurobarometer Survey. In Vienna Inst. of Demography.

Testa, M. R., \& Grilli, L. (2006). The Influence of Childbearing Regional Contexts on Ideal Family Size in Europe. Population, Vol. 61, pp. 109-137. https://doi.org/10.2307/30042114

Trent, R. B. (1980). Evidence bearing on the construct validity of "ideal family size." Population and Environment, 3(3-4), 309-327. https://doi.org/10.1007/BF01255345

Tromans, N., Natamba, E., \& Jefferies, J. (2009). Have women born outside the U.K. driven the rise in U.K. births since 2001? Population Trends, 136(136), 28-42. https://doi.org/10.1057/pt.2009.17

Udry, J. R. (1983). Do couples make fertility plans one birth at a time? Demography, 20(2), 117-128. https://doi.org/10.2307/2061230

University of Essex: Institute for Social and Economic Research. (2020). Understanding Society: Waves 1-9, 2009-2018 and Harmonised BHPS: Waves 1-18, 1991-2009: Special Licence Access. [data collection]. 11th Edition. https://doi.org/http://doi.org/10.5255/UKDA-SN-693110

Zeman, K., Beaujouan, É., Brzozowska, Z., \& Sobotka, T. (2018). Cohort fertility decline in low fertility countries: Decomposition using parity progression ratios. Demographic Research, 
38(25), 651-690. https://doi.org/10.4054/DemRes.2018.38.25 


\section{Appendices}

\section{1) UK Covariates}

\begin{tabular}{|c|c|}
\hline Covariate & Type of variable and justification \\
\hline $\begin{array}{l}\text { Known to have more } \\
\text { than } 1 \text { child }\end{array}$ & $\begin{array}{l}\text { Binary (yes, no) } \\
\text { Reasonable to assume those who go on to have more } \\
\text { children likely to be more pro-natal }\end{array}$ \\
\hline Age at first birth & 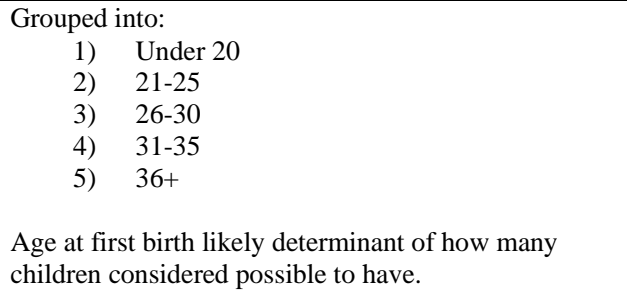 \\
\hline $\begin{array}{l}\text { Expected more than } \\
\text { one child at least } \\
\text { once in } 5 \text { years } \\
\text { before first birth }\end{array}$ & $\begin{array}{l}\text { Binary (yes, no) } \\
\text { Added to disentangle the trajectory of those who } \\
\text { consistently expect } 1 \text { or fewer children before first birth } \\
\text { from those who expect more. }\end{array}$ \\
\hline Year of first birth & $\begin{array}{l}\text { Grouped into: } \\
\text { 1) } 1990-2000 \\
\text { 2) } 2000-2010 \\
\text { Control for year of first birth as the survey is not an age } \\
\text { cohort like the US survey. Added to control for any } \\
\text { differences in childbearing environment (e.g. family } \\
\text { policies, childbearing norms) between the 1990s and } \\
\text { 200s0. }\end{array}$ \\
\hline Partnership status & $\begin{array}{l}\text { Binary (yes, no) based on reported partner ID } \\
\text { Key determinant of childbearing intentions and } \\
\text { outcomes in the UK (Fiori et al., 2014). }\end{array}$ \\
\hline $\begin{array}{l}\text { Highest qualification } \\
\text { attained }\end{array}$ & $\begin{array}{l}\text { Grouped as: } \\
\text { 1) Degree or other higher degree } \\
\text { 2) A-level } \\
\text { 3) GCSE or other qualification } \\
\text { 4) No qualification } \\
\text { Key determinant of fertility intentions and outcomes in } \\
\text { the UK (Berrington et al., 2015). }\end{array}$ \\
\hline
\end{tabular}




\section{2) USA Covariates}

\begin{tabular}{|c|c|}
\hline Covariate & Type of variable and justification \\
\hline $\begin{array}{l}\text { Known to have more } \\
\text { than } 1 \text { child }\end{array}$ & $\begin{array}{l}\text { Binary (yes, no) } \\
\text { Reasonable to assume those who go on to have more children likely to be } \\
\text { more pro-natal }\end{array}$ \\
\hline Age at first birth & $\begin{array}{l}\text { Grouped into: } \\
\text { 6) Under } 20 \\
\text { 7) } 21-25 \\
\text { 8) } 26-30 \\
\text { 9) } 31-35 \\
\text { 10) } 36+ \\
\text { More age groups than in the UK data set as much earlier childbearing } \\
\text { evident in US sample. } \\
\text { Age at first birth likely determinant of how many children considered } \\
\text { possible to have. }\end{array}$ \\
\hline Partnership status & $\begin{array}{l}\text { Binary (yes, no) } \\
\text { Key determinant of intentions in other contents }\end{array}$ \\
\hline $\begin{array}{l}\text { Highest qualification } \\
\text { attained }\end{array}$ & $\begin{array}{l}\text { Grouped as: } \\
\text { 1) Did not finish high school } \\
\text { 2) Finished high school } \\
\text { 3) Attended college } \\
\text { These groups have salience in US context according to other studies. } \\
\text { Important demographic variable. }\end{array}$ \\
\hline Geographical region & $\begin{array}{ll}\text { Grouped by survey as: } \\
-\quad \text { North East } \\
-\quad \text { West } \\
-\quad \text { South } \\
-\quad \text { North Central } \\
\text { As US is such a large study area it is useful to see whether trajectory holds } \\
\text { across the different geographical areas }\end{array}$ \\
\hline Ethnicity & $\begin{aligned} \text { Grouped by survey as: } \\
-\quad \text { Hispanic } \\
-\quad \text { Black } \\
-\quad \text { Non-Hispanic and Non-Black } \\
\text { Ethnic group an important fertility determinant in the US. } \\
\end{aligned}$ \\
\hline $\begin{array}{l}\text { Religious affiliation } \\
\text { in } 1979\end{array}$ & $\begin{array}{l}\text { Grouped as: } \\
\text { 1) None } \\
\text { 2) Protestant } \\
\text { 3) Roman Catholic } \\
\text { 4) Jewish } \\
\text { 5) Other } \\
\text { Category 'Protestant' includes the survey categories Protestant, Baptist, } \\
\text { Episcopalian, Lutheran, Methodist and Presbyterian } \\
\text { The other categories are as coded in the survey. } \\
\text { As data on religious affiliation was sparsely collected, but is unlikely to } \\
\text { vary significantly over time, we used religious affiliation in } 1979 \text { only. }\end{array}$ \\
\hline
\end{tabular}




\section{3) Sensitivity Analysis for UK for one child women}

\begin{tabular}{|c|c|c|c|c|}
\hline & $\begin{array}{l}\text { Empty model (full } \\
\text { sample) } \\
\text { Obs=718, n=192 }\end{array}$ & $\begin{array}{l}\text { Empty model (Over } 45 \text { at last } \\
\text { observation only) } \\
\text { Obs }=396, n=103\end{array}$ & $\begin{array}{l}\text { Model with covariates (full } \\
\text { sample) } \\
\text { Obs =550, } \mathrm{n}=142\end{array}$ & $\begin{array}{l}\text { Model with covariates (Over } 45 \text { at } \\
\text { last observation only) } \\
\text { Obs }=\mathbf{3 0 5}, \mathbf{n}=\mathbf{7 5}\end{array}$ \\
\hline Constant & $1.71 * * *$ & $1.58 * * *$ & $2.15 * * *$ & 2.96 \\
\hline Time & 0.99 & 0.98 & 1.05 & 0.98 \\
\hline \multicolumn{5}{|l|}{$\begin{array}{l}\text { Binary indicator 'not } \\
\text { yet pregnant' (Ref: } \\
\text { yes) }\end{array}$} \\
\hline No & $0.38 * * *$ & $0.42 * * *$ & $0.36 * * *$ & $0.42 * * *$ \\
\hline \multicolumn{5}{|l|}{$\begin{array}{l}\text { Time binary indicator } \\
\text { (Splines after birth, } \\
\text { Ref: Child <0 years } \\
\text { old) }\end{array}$} \\
\hline Child aged $0-12$ months & 1.00 & 0.74 & 0.89 & 0.57 \\
\hline $\begin{array}{l}\text { Child aged 12-24 } \\
\text { months }\end{array}$ & 0.70 & 0.52 & 0.68 & 0.68 \\
\hline $\begin{array}{l}\text { Child aged 24-36 } \\
\text { months }\end{array}$ & 0.73 & 1.14 & 0.97 & 1.13 \\
\hline $\begin{array}{l}\text { Child aged 36-48 } \\
\text { months }\end{array}$ & 0.69 & 0.38 & 0.64 & 0.60 \\
\hline $\begin{array}{l}\text { Child older than } 48 \\
\text { months }\end{array}$ & $0.72 * * *$ & $0.68 \dagger$ & 0.65 *** & $0.53 * *$ \\
\hline \multicolumn{5}{|l|}{$\begin{array}{l}\text { Partnership status } \\
\text { (Ref: No partner) }\end{array}$} \\
\hline Partner & & & 0.86 & 0.87 \\
\hline \multicolumn{5}{|l|}{$\begin{array}{l}\text { Education (Ref: GCSE } \\
\text { or equivalent) }\end{array}$} \\
\hline $\begin{array}{l}\text { Did not finish high } \\
\text { school }\end{array}$ & & & 0.75 & 0.90 \\
\hline A level & & & 0.94 & 1.01 \\
\hline Completed University & & & 1.08 & 1.08 \\
\hline \multicolumn{5}{|l|}{$\begin{array}{l}\text { Age at first birth (Ref: } \\
\text { 21-25) }\end{array}$} \\
\hline 20 and under & & & $0.43 *$ & Omitted (no observations) \\
\hline $26-30$ & & & 0.95 & 0.70 \\
\hline $31-35$ & & & 0.91 & 0.67 \\
\hline $36+$ & & & 0.83 & 0.65 \\
\hline \multicolumn{5}{|l|}{$\begin{array}{l}\text { Age at first birth } x \\
\text { Time (Ref: } 21-25 \text { ) }\end{array}$} \\
\hline 20 and under & & & $1.19 *$ & Omitted (no observations) \\
\hline $26-30$ & & & 1.04 & 1.14 \\
\hline $31-35$ & & & 0.95 & 1.03 \\
\hline $36+$ & & & 0.89 * & 0.93 \\
\hline \multicolumn{5}{|l|}{$\begin{array}{l}\text { Expectations before } \\
\text { first birth (Ref: } 2 \\
\text { expected at least once) }\end{array}$} \\
\hline $\begin{array}{l}\text { Never expected } 2 \text { at } \\
\text { least once }\end{array}$ & & & $0.36^{* * *}$ & $0.38 * * *$ \\
\hline \multicolumn{5}{|l|}{$\begin{array}{l}\begin{array}{l}\text { Decade of first birth } \\
\text { (ref: 1990-1999) }\end{array} \\
\end{array}$} \\
\hline $2000-2010$ & & & 1.06 & 1.00 \\
\hline
\end{tabular}

$* * * \mathrm{p}<0.005, * * \mathrm{p}<0.01, * \mathrm{p}<0.05, \dagger \mathrm{p}<0.1$ 

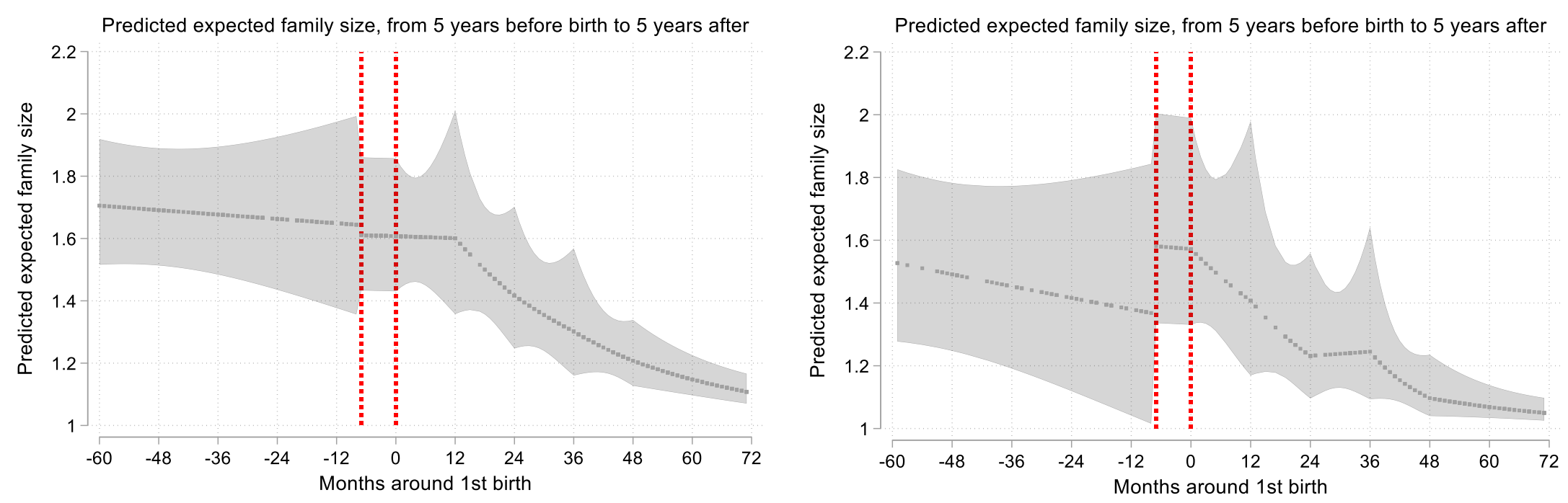

For comparison, on the left is the 'empty' model fitted for the whole sample ( $\mathrm{n}=192)$, and on the right, is the same model fitted only for women who were 45 or older at last observation $(n=103)$ 


\section{4) Data Sources Comparison}

\begin{tabular}{|c|c|c|}
\hline & UK (BHPS and UKHLS) & USA (NLSY'79) \\
\hline $\begin{array}{l}\text { Type of } \\
\text { survey }\end{array}$ & Household panel & Cohort of women aged 14-22 in 1979 \\
\hline $\begin{array}{l}\text { Sample } \\
\text { selection }\end{array}$ & $\begin{array}{l}\text { 1) Women with at least one child, under } \\
45 \text {, complete information, at least } 3 \\
\text { repeat observations, } 1^{\text {st }} \text { child born } \\
\text { prior to } 1990 \text { and including a censor } \\
\text { at second childbirth } \\
\text { 2) } 1 \text { child women only }\end{array}$ & $\begin{array}{l}\text { 1) Women with at least one child, } \\
\text { under } 45 \text {, complete information, } \\
\text { at least } 3 \text { repeat observations and } \\
\text { including a censor at second } \\
\text { childbirth } \\
\text { 2) } 1 \text { child women only }\end{array}$ \\
\hline Sample size & $\begin{array}{l}\text { 1) } 303 \text { individuals, } 1102 \text { observations } \\
\text { 2) } 192 \text { individuals, } 718 \text { observations }\end{array}$ & $\begin{array}{l}3652 \text { women, } 18145 \\
\text { observations } \\
\text { 2) } 1078 \text { women, } 5782 \text { observations }\end{array}$ \\
\hline $\begin{array}{l}\text { Outcome } \\
\text { variable }\end{array}$ & $\begin{array}{l}\text { Expected family size (current number of } \\
\text { children plus number of additional children } \\
\text { expected) }\end{array}$ & $\begin{array}{l}\text { Expected family size (current number of } \\
\text { children plus number of additional } \\
\text { children expected) }\end{array}$ \\
\hline Time period & $1992-2013$ & $1979-2014$ \\
\hline $\begin{array}{l}\text { Covariates } \\
\text { shared across } \\
\text { data sets }\end{array}$ & $\begin{array}{ll} & \text { Whether respondent went on to have a } \\
\text { - } & \text { Age at first birth } \\
\text { - } & \text { Relationship status } \\
\text { - } & \text { Highest qualification attained }\end{array}$ & $2^{\text {nd }}$ child \\
\hline $\begin{array}{l}\text { Differing } \\
\text { covariates } \\
\text { across data } \\
\text { sets }\end{array}$ & - $\quad$ Year of first birth & $\begin{array}{ll}- & \text { Geographical area } \\
- & \text { Ethnicity } \\
- & \text { Religious affiliation }\end{array}$ \\
\hline
\end{tabular}


5) Empty UK (left) and Empty USA (right) models of additional number of children expected, with no modifications
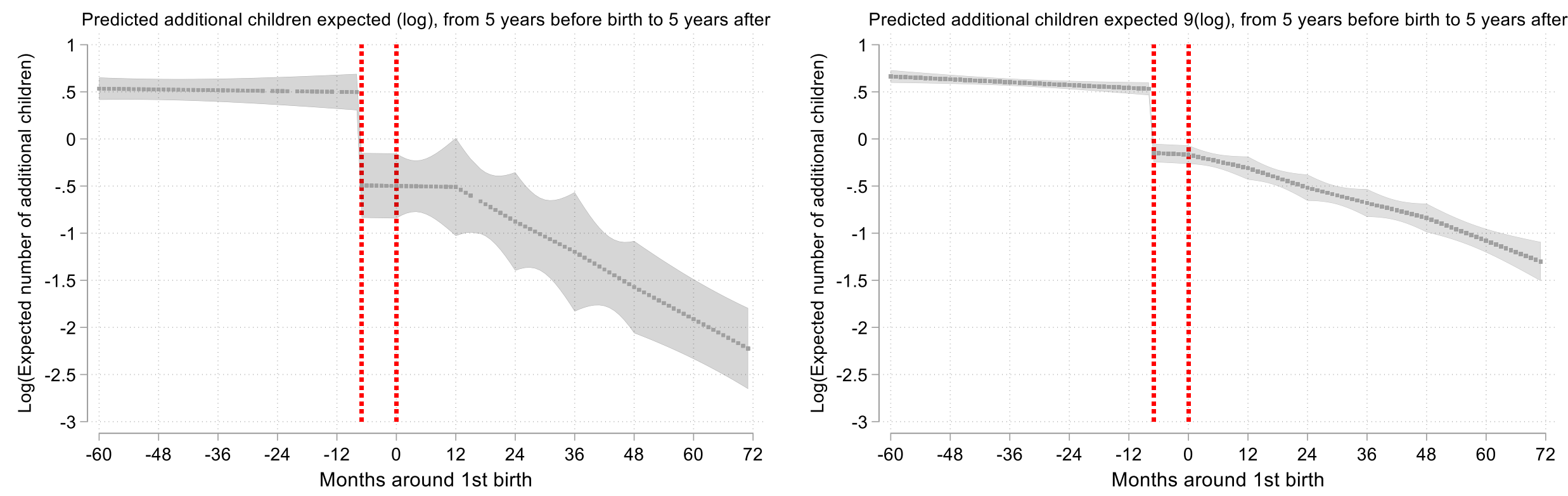


\section{6) Empty UK (left) and Empty USA (right) models of additional number of children expected, with only one spline at 2 months pregnant}
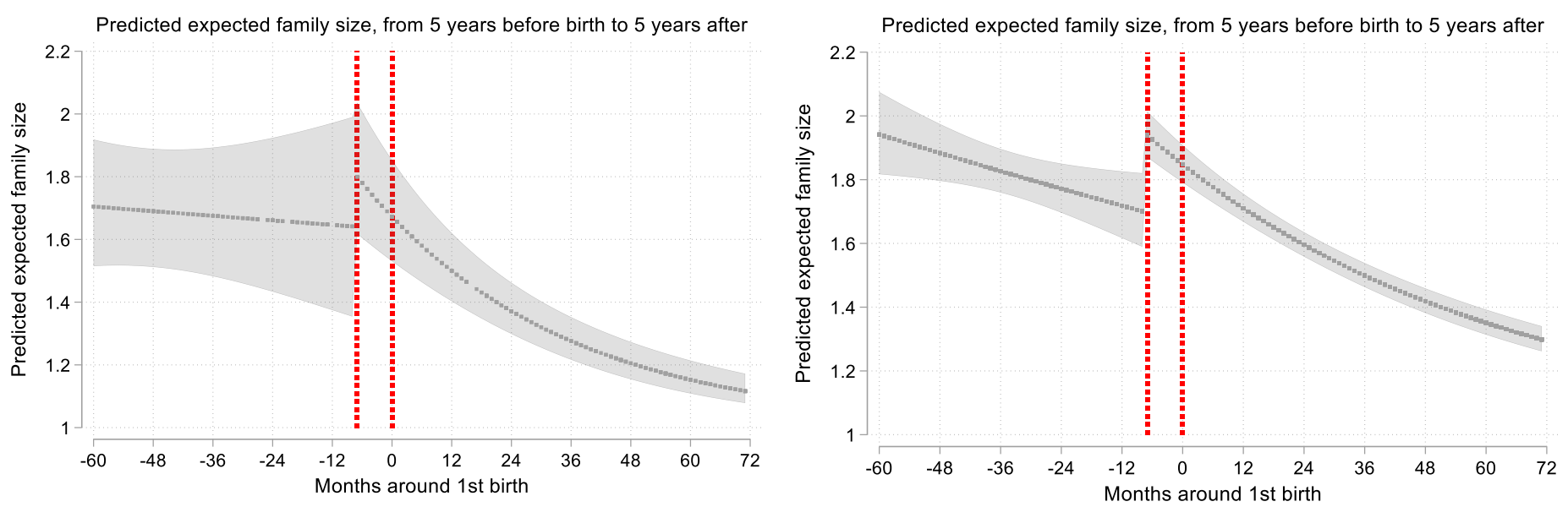

\begin{tabular}{|c|c|c|c|c|}
\hline & Meaning & Levels & $\begin{array}{l}\text { UK one child } \\
\text { women (718 } \\
\text { obs, } n=192)\end{array}$ & $\begin{array}{l}\text { USA one child women } \\
\text { (5770 obs, } n=1078)\end{array}$ \\
\hline Constant & Intercept of the model & NA & $1.71 * * *$ & $1.94 * * *$ \\
\hline Time & $\begin{array}{l}\text { Baseline effect per } 12 \\
\text { months }\end{array}$ & $\begin{array}{l}\text { Linear, } 0 \text { is the intercept ( } 5 \text { years } \\
\text { before birth) }\end{array}$ & 0.99 & $0.97 *$ \\
\hline \multirow{3}{*}{$\begin{array}{l}\text { Binary indicator 'not } \\
\text { yet pregnant' }\end{array}$} & \multirow{3}{*}{$\begin{array}{l}\text { Changes in additional } \\
\text { number of children } \\
\text { expected when the } \\
\text { arrival of the first child } \\
\text { is confirmed }\end{array}$} & Time $<-7$ months from birth & Ref & Ref \\
\hline & & & & \\
\hline & & Time $=>-7$ months from birth & $0.49 * * *$ & $0.55 * * *$ \\
\hline \multirow{2}{*}{$\begin{array}{l}\text { Time binary } \\
\text { indicator (Spline at } 2 \\
\text { months pregnant) }\end{array}$} & \multirow{2}{*}{$\begin{array}{l}\text { Changes in } \\
\text { expectation after } \\
\text { realisation of } \\
\text { pregnancy }\end{array}$} & Before 2 months pregnant & Ref & Ref \\
\hline & & After 2 months pregnant & $0.75 * * *$ & $0.86 * * *$ \\
\hline
\end{tabular}

Incidence rate ratios for one child women in the UK (column 4) and USA (column 5). Column 1 lists the variable, column 2 the variables meaning, and column 3 the categories of the variable.

$* * * \mathrm{p}<0.005, * * \mathrm{p}<0.01, * \mathrm{p}<0.05, \dagger \mathrm{p}<0.1$ 
7) UK Models - Univariable analyses (each variable listed in the rows is a separate model) for one child women

\begin{tabular}{|c|c|c|c|c|}
\hline & $\mathbf{N}$ & Variable IRR & Time IRR & $\begin{array}{l}\text { Variable } x \text { Time } \\
\text { Interaction IRR }\end{array}$ \\
\hline \multicolumn{5}{|c|}{ Partnership status (Ref: No partner) } \\
\hline Partner/spouse & $\begin{array}{c}\text { Obs }=718 \\
n=192\end{array}$ & $\begin{array}{c}0.87 \\
(0.70-1.09) \\
\end{array}$ & $\begin{array}{c}1.00 \\
(0.95-1.06) \\
\end{array}$ & $\begin{array}{c}1.00 \\
(0.95-1.06) \\
\end{array}$ \\
\hline \multicolumn{5}{|l|}{$\begin{array}{l}\text { Education (Ref: Completed } \\
\text { University) }\end{array}$} \\
\hline Did not finish high school & \multirow{3}{*}{$\begin{array}{c}\text { Obs }=718 \\
\mathrm{n}=192\end{array}$} & $\begin{array}{c}0.81 \\
(0.40-1.64) \\
\end{array}$ & \multirow{3}{*}{$\begin{array}{c}0.97 \\
(0.91-1.03)\end{array}$} & $\begin{array}{c}1.09 \\
(0.95-1.25) \\
\end{array}$ \\
\hline GCSE or equivalent qualification & & $\begin{array}{c}0.88 \\
(0.68-1.13) \\
\end{array}$ & & $\begin{array}{c}1.05 \\
(0.98-1.12) \\
\end{array}$ \\
\hline A level & & $\begin{array}{c}0.90 \\
(0.67-1.22) \\
\end{array}$ & & $\begin{array}{c}1.02 \\
(0.95-1.10) \\
\end{array}$ \\
\hline \multicolumn{5}{|l|}{ Age at first birth (Ref: Under 20) } \\
\hline $21-25$ & \multirow{4}{*}{$\begin{array}{c}\text { Obs }=718 \\
\mathrm{n}=192\end{array}$} & $\begin{array}{c}2.06 \dagger \\
(0.96-4.44)\end{array}$ & \multirow{4}{*}{$\begin{array}{c}1.20 * * \\
(1.05-1.37)\end{array}$} & $\begin{array}{c}0.88 * \\
(0.77-1.00)\end{array}$ \\
\hline $26-30$ & & $\begin{array}{c}1.78 \\
(0.85-3.70)\end{array}$ & & $\begin{array}{c}0.90 \dagger \\
(0.80-1.01)\end{array}$ \\
\hline $31-35$ & & $\begin{array}{c}1.72 \\
(0.82-3.60)\end{array}$ & & $\begin{array}{c}0.81 * * * \\
(0.71-0.92)\end{array}$ \\
\hline $36+$ & & $\begin{array}{c}1.46 \\
(0.68-3.13)\end{array}$ & & $\begin{array}{c}0.75 * * * \\
(0.65-0.87)\end{array}$ \\
\hline \multicolumn{5}{|l|}{$\begin{array}{l}\text { Expectation before first birth (Ref: } \\
\text { Expected } 1 \text { or none) }\end{array}$} \\
\hline 2 expected at least once & $\begin{array}{l}\mathrm{Obs}=550 \\
\mathrm{n}=142\end{array}$ & $\begin{array}{c}3.58 * * * \\
(2.17-5.93)\end{array}$ & $\begin{array}{c}1.04 \\
(0.86-1.07)\end{array}$ & $\begin{array}{c}0.96 \\
(0.86-1.07)\end{array}$ \\
\hline \multicolumn{5}{|c|}{ Decade of first birth (Ref: 1990-1999) } \\
\hline $2000-2010$ & $\begin{array}{c}\text { Obs }=718 \\
\mathrm{n}=192\end{array}$ & $\begin{array}{c}1.14 \\
(0.84-1.56) \\
\end{array}$ & $\begin{array}{c}1.00 \\
(0.92-1.07) \\
\end{array}$ & $\begin{array}{c}1.01 \\
(0.94-1.08) \\
\end{array}$ \\
\hline
\end{tabular}


8) US models - Univariable analyses for one child women

\begin{tabular}{|c|c|c|c|c|}
\hline & $\mathbf{n}$ & Variable IRR & Time IRR & $\begin{array}{l}\text { Variable } x \text { Time } \\
\text { Interaction IRR }\end{array}$ \\
\hline \multicolumn{5}{|c|}{ Partnership status (Ref: No partner) } \\
\hline Partner/spouse & $\begin{array}{c}\text { Obs }=5770 \\
N=1078\end{array}$ & $\begin{array}{c}0.96 \\
(0.90-1.02) \\
\end{array}$ & $\begin{array}{c}0.97 \dagger \\
(0.95-1.00) \\
\end{array}$ & $\begin{array}{c}0.99 \\
(0.97-1.01) \\
\end{array}$ \\
\hline \multicolumn{5}{|l|}{ Education (Ref: Attended college) } \\
\hline Did not finish high school & \multirow{2}{*}{$\begin{array}{c}\text { Obs }=5752 \\
n=1078\end{array}$} & $\begin{array}{c}1.11 \\
(0.97-1.27)\end{array}$ & \multirow{2}{*}{$\begin{array}{c}0.97 * \\
(0.94-1.00)\end{array}$} & $\begin{array}{c}1.01 \\
(0.97-1.04)\end{array}$ \\
\hline Finished high school & & $\begin{array}{c}1.07 \\
(0.96-1.18) \\
\end{array}$ & & $\begin{array}{c}1.00 \\
(0.98-1.02) \\
\end{array}$ \\
\hline \multicolumn{5}{|l|}{ Age at first birth (Ref: Under 20) } \\
\hline $21-25$ & \multirow{4}{*}{$\begin{array}{c}\text { Obs }=5770 \\
n=1078\end{array}$} & $\begin{array}{c}0.93 \\
(0.79-1.00)\end{array}$ & \multirow{4}{*}{$\begin{array}{c}1.00 \\
(0.96-1.03)\end{array}$} & $\begin{array}{c}0.99 \\
(0.96-1.02)\end{array}$ \\
\hline $26-30$ & & $\begin{array}{c}0.91 \\
(0.77-1.07) \\
\end{array}$ & & $\begin{array}{c}0.96 * * \\
(0.93-0.99) \\
\end{array}$ \\
\hline $31-35$ & & $\begin{array}{c}0.78 * \\
(0.64-0.95)\end{array}$ & & $\begin{array}{c}0.92 * * * \\
(0.88-0.96)\end{array}$ \\
\hline $36+$ & & $\begin{array}{c}0.56 * * * \\
(0.43-0.72) \\
\end{array}$ & & $\begin{array}{c}0.88 * * * \\
(0.83-0.94) \\
\end{array}$ \\
\hline \multicolumn{5}{|l|}{ Ethnic Group (Ref: Hispanic) } \\
\hline Black & \multirow{2}{*}{$\begin{array}{c}\text { Obs }=5770 \\
n=1078\end{array}$} & $\begin{array}{c}0.90 \\
(0.77-1.06) \\
\end{array}$ & \multirow{2}{*}{$\begin{array}{c}0.96 * \\
(0.92-1.00)\end{array}$} & $\begin{array}{c}1.01 \\
(0.98-1.05)\end{array}$ \\
\hline Not Black or Hispanic & & $\begin{array}{c}0.95 \\
(0.83-1.10) \\
\end{array}$ & & $\begin{array}{c}1.01 \\
(0.98-1.05) \\
\end{array}$ \\
\hline \multicolumn{5}{|l|}{ Geographical Region (Ref: West) } \\
\hline North East & \multirow{3}{*}{$\begin{array}{c}\text { Obs }=5715 \\
n=1075\end{array}$} & $\begin{array}{c}0.96 \\
(0.82-1.11) \\
\end{array}$ & \multirow{3}{*}{$\begin{array}{c}0.97 \dagger \\
(0.94-1.01)\end{array}$} & $\begin{array}{c}1.00 \\
(0.97-1.04) \\
\end{array}$ \\
\hline North Central & & $\begin{array}{c}0.96 \\
(0.83-1.11) \\
\end{array}$ & & $\begin{array}{c}1.01 \\
(0.98-1.04) \\
\end{array}$ \\
\hline South & & $\begin{array}{c}0.92 \\
(0.81-1.05) \\
\end{array}$ & & $\begin{array}{c}0.99 \\
(0.96-1.02) \\
\end{array}$ \\
\hline \multicolumn{5}{|c|}{ Religious affiliation 1979 (ref: no religion) } \\
\hline Protestant & \multirow{4}{*}{$\begin{array}{c}\text { Obs }=5735 \\
n=1072\end{array}$} & $\begin{array}{c}0.89 \\
(0.75-1.05) \\
\end{array}$ & \multirow{4}{*}{$\begin{array}{c}0.96^{*} \\
(0.92-1.00)\end{array}$} & $\begin{array}{c}1.01 \\
(0.98-1.06) \\
\end{array}$ \\
\hline Catholic & & $\begin{array}{c}0.97 \\
(0.82-1.15) \\
\end{array}$ & & $\begin{array}{c}1.03 \\
(0.99-1.07) \\
\end{array}$ \\
\hline Jewish & & $\begin{array}{c}1.15 \\
(0.66-2.01) \\
\end{array}$ & & $\begin{array}{c}0.93 \\
(0.81-1.06) \\
\end{array}$ \\
\hline Other & & $\begin{array}{c}1.09 \\
(0.89-1.33) \\
\end{array}$ & & $\begin{array}{c}1.00 \\
(0.95-1.05) \\
\end{array}$ \\
\hline \multicolumn{5}{|c|}{$\begin{array}{l}\text { Expectation before first birth (Ref: Never } \\
\text { expected } 2 \text { at least once) }\end{array}$} \\
\hline Expected 2 children at least once & $\begin{array}{c}\text { Obs }=5480 \\
n=997\end{array}$ & $\begin{array}{c}4.31 * * * \\
(3.51-5.30)\end{array}$ & $\begin{array}{c}1.03 \\
(0.99-1.08)\end{array}$ & $\begin{array}{c}0.93 * * * \\
(0.90-0.97)\end{array}$ \\
\hline
\end{tabular}




\section{9) USA regional model figure}

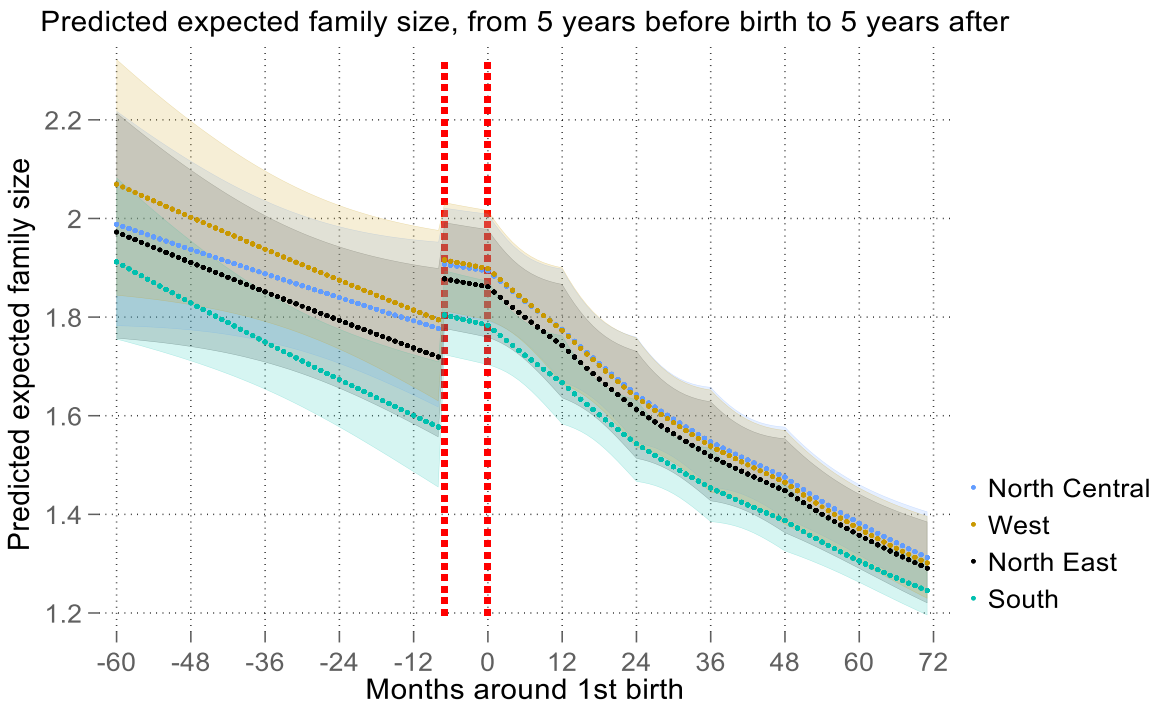

Predicted expected family size (modelled with random intercept and random slope) from 5 years before to 5 years after first birth in the US stratified by region for one child women. Shaded areas correspond to $95 \%$ confidence intervals. Colour of the shaded areas correspond to the line they are calculated for. 